\title{
Shoreline Dynamics of Reserved Region of Meghna Estuary and It Impacts on Lulc and Socio-Economic: A Case Study on Nijhum Dwip
}

Piash Chowdhury ( $\square$ piashcowdhury@student.sust.edu )

Shahjalal University of Science and Technology

Md. Bahuddin Sikder

Shahjalal University of Science and Technology

\section{Research Article}

Keywords: Erosion-accretion, Succession, Migration, Economic activities, Habitation conditions, Tourism

Posted Date: January 25th, 2022

DOl: https://doi.org/10.21203/rs.3.rs-555094/v1

License: (c) (1) This work is licensed under a Creative Commons Attribution 4.0 International License.

Read Full License 
SHORELINE DYNAMICS OF RESERVED REGION OF MEGHNA ESTUARY AND IT IMPACTS ON LULC AND SOCIO-ECONOMIC: A CASE STUDY ON NIJHUM DWIP Piash Chowdhury ${ }^{1 *}$, Md. Bahuddin Sikder ${ }^{2}$

${ }^{1}$ MS Student, Department of Geography and Environment, Shahjalal University of Science and Technology, Sylhet -3114, Bangladesh.

${ }^{2}$ Assistant Professor, Department of Geography and Environment, Shahjalal University of Science and Technology, Sylhet -3114 , Bangladesh.

Email of Corresponding Author *: piashcowdhury@student.sust.edu 


\begin{abstract}
Abstruct
The southern side of Bangladesh is more unstable due to carrying massive discharge and transportation of heavy sediment through Meghna estuary. Shoreline representation is extremely important to regulate the dynamic nature of coastal areas. This paper focused on measuring the change of shoreline, evaluating the LULC (land use \& land cover) due to the shoreline dynamics by using a multi-date (1978-2018) satellite image and changes of the social-economic condition due to the shoreline dynamics by a direct interview-based questionnaire survey of Nijhum Dwip, Hatiya, Noakhali, Bangladesh. Shoreline changes have been estimated as net shoreline movement (NSM), endpoint rate (EPR), and prediction based on the EPR rate. A total of $104 \%$ were increased with the rate of $-17 \mathrm{~m}$ to $86 \mathrm{~m}$ per year shoreline change. Most of the accretion occurred in the Northern and Western sides; erosion only occurred on the Southern side. It can be estimated that the shoreline will increase by $2.2 \mathrm{~km}$, with an area of 644.32 hectares in 2028 . LULC mainly changed due to accretion activities in the study area. Barren land, mudflats, homestead vegetation, grassland were increased by $0.63 \%, 0.65 \%, 14 \%, 6 \%$ drastically of its total area, respectively. Cropland, green vegetation, and mangrove vegetation were decreased by $12 \%, 9 \%$, and $0.11 \%$, respectively, drastically of its total area. It can be appraised that the vegetated area will increase 5103.39 hectares in 2028. Thus it was also determined that shoreline change has a positive impact on migration, economic activities, and tourism. As newly accreted land which was cheap or could stay through "Bndobostho" and people were joining various working fields which had been created in new accreted land and farmer were increased. This paper intends to contribute several suggestions to the socio-economic development of native people and future strategic management of the reserved coastal area.
\end{abstract}

Keywords: Erosion-accretion, Succession, Migration, Economic activities, Habitation conditions, Tourism 


\section{INTRODUCTION}

Bangladesh is a lowland deltaic country and lies at the mouth of two of the largest rivers in the world, the Ganges and the Brahmaputra, draining from the Himalayan massif transport sediment from its most catchment areas in the transboundary region. The combined flow of the GangesBrahmaputra-Meghna (GBM) is drained through the Lower Meghna river into the Bay of Bengal through the Meghna estuary (Wilde, 2011) Among the large rivers in the world, the mutual flow of the GBM Rivers ranks third in terms of water flow and first in terms of total sediment load (Milliman, 1991). The sediments which are kept in the bed of the channel and the stream of estuary brings about an adjustment in the hydrology by diminishing the water understanding in various pieces of the estuary through the normal procedure of accretion is offering rise to new chars land along a noteworthy part of the $710 \mathrm{~km}$ of coast. The bed of the Meghna Estuary comprises of sediment, and fine sand with a middle bed material grain and $50 \%$ forest were in the coastal zone (PDO-ICZMP, 2004). The coast is referred to as a zone of exposures just as circumstances with its one of a kind significance for characteristic assets and environments. It is arranged for catastrophic events like violent winds, storm floods, and beachfront floods. The mix of characteristic and human-made dangers, for example, disintegration, high arsenic content in groundwater, water-logging, seismic tremor, water and soil saltiness, subsidence, dangers from an environmental change like ocean level ascent, and so on have unfavourably influenced the lives and employments, and morphology of beachfront zone, and hindered the pace of social and monetary improvements in the delta area (MoWR, 2005). Shoreline change is apparent as a major problem, mainly in the delta region all over the world. Shoreline or coastline generally defined as the line of interaction between land and water body, which is dynamic in nature (Pajak \& Leatherman, 2002); (Cui \& Li, 2011). The landform dynamics of coastal areas has been a major concern to the researchers. The dynamic nature of shoreline makes it difficult to tide lineate how much area is accredited or eroded by the time (Fenster, et al., 2001). Several factors trigger the transformation of shoreline, for example, sea-level rise, storm surge, wind, wave tide, etc., (Orford, et al., 2002); (Cooper, et al., 2004). Shoreline change analysis and prediction are important for cohesive coastal zone management in Bangladesh as the bay of Bangla was adjoining about $113 . \mathrm{km}$ of the coast over the time interval 1973 to 2003 in the Indian region (Maiti \& Bhattacharya, 2009). The charred lands situated in Meghna estuary were characterized by the coastal erosion and accretion areas during 1973-2016 that the results revealed $32 \mathrm{~km}^{2} \mathrm{y}^{-1}$ 
net accretions. The northern part of Bhola island and southern part of Lakshmipur eroded during 1973-1988, which may be attributed to increased river flow during monsoon in the Lower Meghna river. The erosion of Sandwip, Urirchar, and the south-eastern part of Noakhali during 1988-2016 may be occurred due to the reverse flow of seawater through Sandwip channel to the north in the deeper seabed (Hasan, et al., 2017). The Nijum dwip, also situated in Meghna estuary, which is extremely powerful and exceptional because of island position and hydrogeomorphic settings. The island has been encountering extreme morphological and hydrological changes over time because of consolidating the impacts of the estuary and tidal impacts of the Bay of Bengal.

A Forest cover change is also a dynamic, extensive, and fast-tracking process, mainly driven by natural phenomena and anthropogenic actions. Bangladesh is losing 3.5\% of her forest every year. The annual rate of negative change of forest cover during 2000-2005 was 2000 hectors per year (FAO, 2005). In most recent a very long while, deforestation and biodiversity misfortune turned into a typical occasion all through the globe. To ensure the timberland and ration, biodiversity worldwide, numerous regions announced as a secured territory, which is somewhat another idea. Till now, the nation has just nineteen informed ensured territories, including Nijhum Dwip (Abdul \& Islam, 2005) Protected areas restrict the access and utilization of forest products to local livelihoods that they have enjoyed customarily. They are in the form of a national park, game reserve, wildlife sanctuary, fish sanctuary, world heritage sites, Ramsar sites, a marine reserve, and ecologically critical areas (PDO-ICZMP, 2004) . Increasing in relative sealevel rise (RSL) has been connected to beachfront wetland misfortunes. Lower surface heights bring about more noteworthy recurrence and term of tidal flooding, and in this manner in expanded peat immersion, saltiness, and sulfide focuses, and in diminished redox potential, as straightforwardly estimated over the developing season at both changed and stable destinations. Accordingly, vegetation change happened (Warren \& Niering, 1993), With the change of shoreline, the succession process will start. Succession is a directional non-seasonal cumulative change in the types of plant species that occupy a given area through time. It involves the processes of colonization, establishment, and extinction, which act on the participating plant species (Pidwirny, 2006).

Indeed, the cited effects of coastal erosion included the decrease of agricultural land, destruction of coastal properties, and reduced fish catches. It emerged that the most common mitigating 
action taken by coastal communities is the planting of vegetation, while some hotel establishments erected seawalls along the shoreline. There is a need to develop proper interventions for sustainable coastal resource utilization (Mwanj, 1997). The coastal area is essential for residents, recreation, tourism, fisheries, and agriculture as a source of socioeconomic development of the local community. Some of the activities will affect the coastline changes. However, coastline changes occur in the coastal areas will affect socio-economic for the local community. Identification of risk coastal areas needs to be done for the society and local authorities to be prepared for coastline changes (Hassan \& Rahmat, 2016). The fishermen of Nijhum Dwip have lived in an extremely dynamic environment facing tropical cyclones, tidal surges, embankment erosion and salinity intrusion that affect life and livelihood options (Hossain, et al., 2013).

With the above background, this paper tries to assess shoreline shifting and erosion-accretion rate, analysis Land use and land cover change due to shoreline shifting and assess the diversification of social-economic conditions on the dwellers of Nijhum Dwip that can provide the possible answer in movability pattern of shoreline Meghna estuarine chars through this study, Potentials, and challenges to the development of southern-most char land will be comprehensible through this study. Citation of some suggestions for the socio-economic development of native people and future strategic management of the reserved coastal area. This study can be used by the researcher to find out the vulnerable situation in the study area and help the policymakers to take any decision regarding the probable impact of comprehension shoreline shifting.

\subsection{Study Area}

Nijhum Dwip Island under Hatiya Upazila of Noakhali district in Bangladesh is the southernmost island of the country that confluences of Meghna estuary of Bengal (South and West). It is about $120 \mathrm{~km}$ south of Maijdee bazaar, Sadar, Noakhali District, Chattrogram Division. The Absolute location of Nijum Dwip is $22^{\circ} 6^{\prime} 8^{\prime \prime} \mathrm{N}$ to $22^{\circ} 1^{\prime} 32^{\prime \prime} \mathrm{N}$ and $90^{\circ} 58^{\prime} 22^{\prime \prime} \mathrm{E}$ to 912'51"E (Figure:1). It environmentally protects area is in Under Noakhali Forest Division. Noakhali Forest Division (NFD) is one of the four coastal forest divisions of Bangladesh, which lies in the south-eastern zone of the country. About 4565 hectares area is observed in the study area. Among it, about 2023.428 hectares are Nijhum Dwip Reserved, which is under the authorization of the Bangladesh forest department, and the rest of the area is under union. In the 
1940s, the cluster of islands started to emerge, and the surface of the islands began to sustainable near 1972. This island was brought under settlement during 1969 by a cowboy named Osman that why it is called char Osman. It is also called Island of silence or Balur char. In 1974, plantation programs were stared the north side of the island (Rahman, 2010). In 1978, four pairs of spotted deer were released in the forest, and now the number of deer has increased to around 14400 (According to a census carried out in 2006) under the Bangladesh Wildlife Act 1974. Bangladesh government was declared Nijhum Dwip as a National park on 8 April 2001. The most outstanding feature is Around $20 \mathrm{~km}$ sandy, and grassy beach found here.
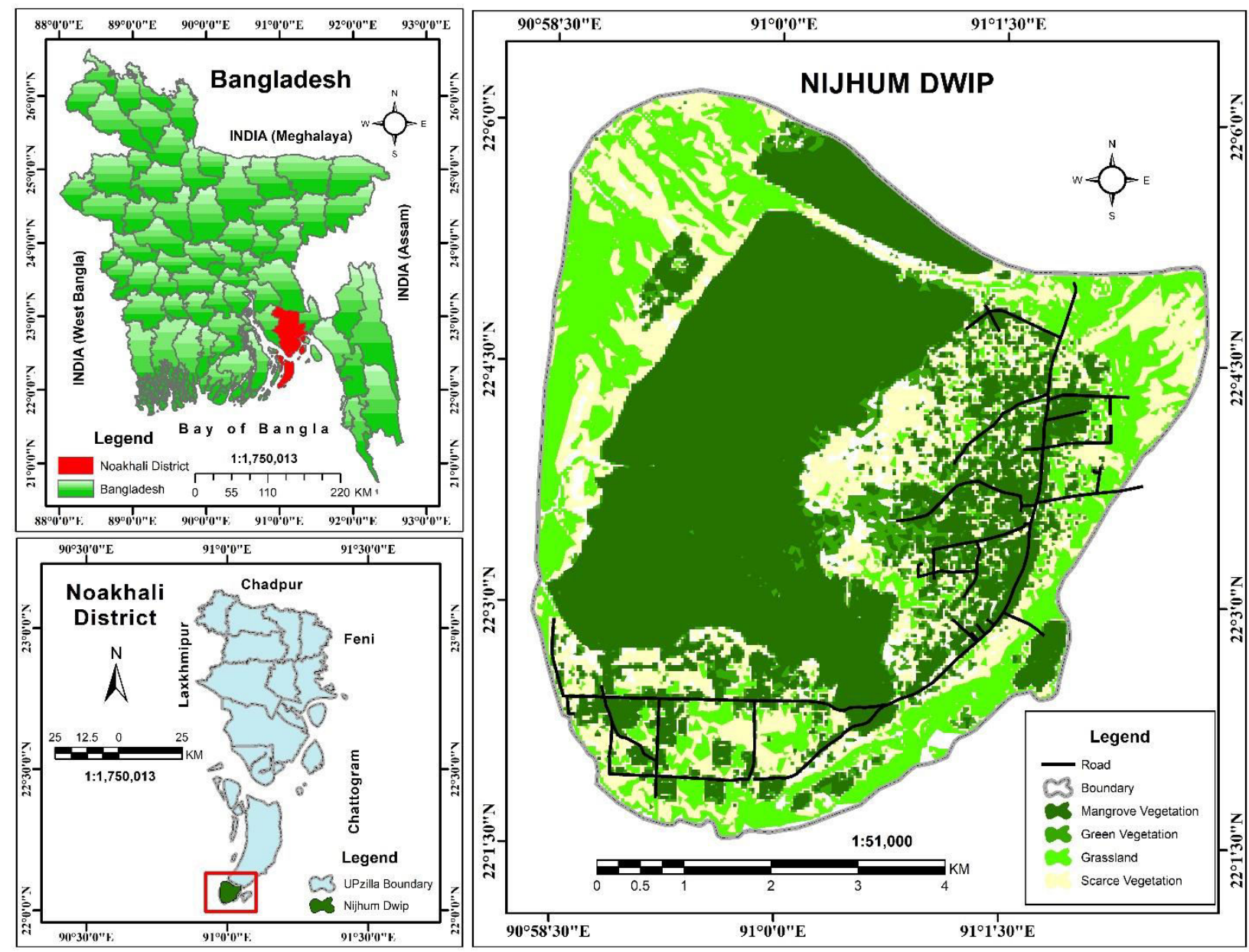

Figure 1: Map of the Study Area

[[Data Source: NASA LP DAAC, 2018 \& OSM]

The island is about 2.2 meters high from the sea level (Shaha, et al., 2014). Mudflats are very unstable due to estuarine activities in this region, that is why it is selected as the study area. The highest mean annual sea level was in 1998 (3360mm) and the lowest mean annual sea level in 1988 (1050mm) (Figure 2). 


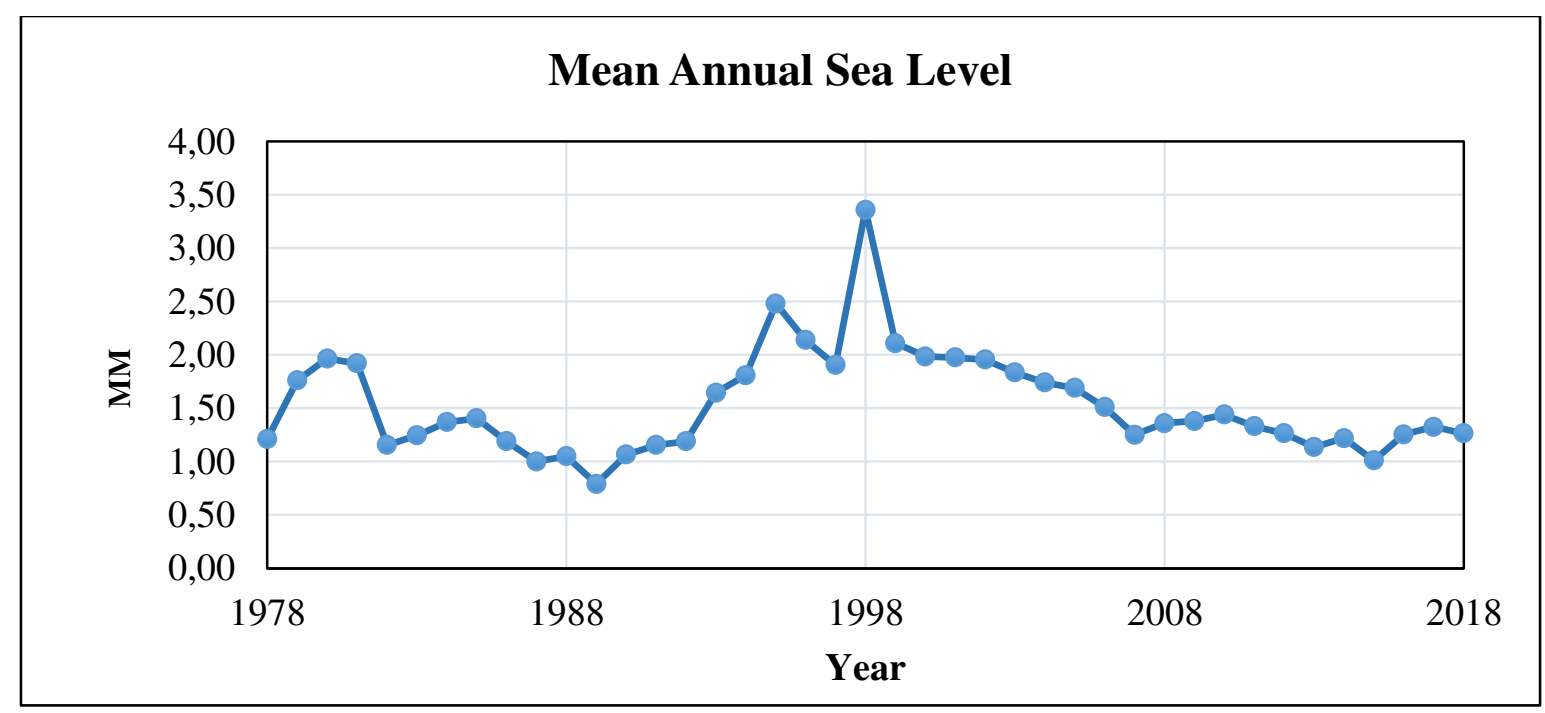

[Source-Bangladesh Water Development Board]

Figure 2: Trend of MASL from the Period of 1978 to 2018

Soil salinity ranged from 1.6 to 25.6 , with a mean of $11.3 \mathrm{dS} / \mathrm{m}$ in 2004 at the study are (Sattar \& Mutsaers, 2004) Only about $25 \%$ of areas are non-saline to slightly saline (ECe $0-8 \mathrm{dS} / \mathrm{m}$ ). Most part (about $63 \%$ ) of the area is saline to strongly saline $(8-16 \mathrm{dS} / \mathrm{m})$, while the rest $12 \%$ is extremely saline (>16 dS/m), which is an embankment of the study area.

Table 1: Soil salinity of the Study Area

\begin{tabular}{ccccc}
\hline & \multicolumn{2}{c}{2001} & \multicolumn{2}{c}{$\mathbf{2 0 0 4}$} \\
\hline Year & Range & Mean & Range & Mean \\
\hline $\begin{array}{c}\text { Salinity } \\
\text { (ECe,dS/m) }\end{array}$ & $3.8-60.7$ & 42.3 & $1.6-25.6$ & 11.3 \\
\hline
\end{tabular}

[Source: Char Development \& Settlement Project II report] According to the census, the population of the study area is 64983, of which $1813(50.39 \%)$ are males, and 17757 are female (47.68\%). Of the male adults, about $60 \%$ and $40 \%$ are young. Of the females, adults are $45 \%$, and $55 \%$ are young. From the primary data observation, most of the villagers are Muslims except Some Few, and most of them are fishermen, and some are agriculturists. Most of the houses are made of wood, tin, and timber. People are mostly illiterate (90\%), $8 \%$ person people can read and write only, $1 \%$ secondary, and $1 \%$ higher studies. In the present time, every about ten households have one tube-well for drinking water. Very few paved roads are there, but those roads also need to be repaired. There has no connection by bus or air as there is no land connection or airport facilities. There are more than three ways to reach Nijhum 
Dwip. Only hospitals have two sits in which doctors are not available. There is no proper educational institution.

\section{MATERIALS AND METHODS}

\subsection{Data Used}

Multi-temporal satellite data of Lands at MSS, TM, and ETM+ of different periods have been used in this study. However, the satellite images could not be collected at regular intervals due to the unavailability of cloud-free imagery during the chosen period. The details of the satellite data are given in Table 2 .

\begin{tabular}{lccccc}
\hline Satellite & $\begin{array}{c}\text { Sensor } \\
\text { type }\end{array}$ & Paths/Rows & $\begin{array}{c}\text { Acquisition } \\
\text { Date }\end{array}$ & Resolution & Data Type \\
\hline Landsat 8 & OLI/ TIRS & $136 / 45$ & $11 / 29 / 2018$ & $30 \mathrm{~m}$ & Level 1 \\
\hline Landsat 5 & TM & $136 / 45$ & $11 / 01 / 2008$ & $30 \mathrm{~m}$ & Level 1 \\
\hline Landsat 5 & TM & $136 / 45$ & $12 / 08 / 1998$ & $30 \mathrm{~m}$ & Level 1 \\
\hline Landsat 5 & TM & $136 / 45$ & $11 / 10 / 1988$ & $30 \mathrm{~m}$ & Level 1 \\
\hline Landsat 2 & MSS & $147 / 45$ & $11 / 18 / 1978$ & $60 \mathrm{~m}$ & Level 1 \\
\hline
\end{tabular}

Table 2: The Imaginary which used to study the shoreline Change

To find out the socio-economic conditions of the study area, conducted a field survey in April 2019 based on the questionnaire survey. To carry out the questionnaire survey, among 35983 people, randomly choose 397 by following Solvin's formula and keeping the confidence level at $95 \%$. The formula

$$
\operatorname{Sample} \operatorname{Size}(\boldsymbol{n})=N / 1+N e^{2}
$$

Here,

$\mathrm{N}=$ Total population (total number of household) and

$\mathrm{e}=$ margin of error

\subsection{Software Used}

In this study, we used the Environmental Systems Research Institute's ArcGIS 10.5 software for purposes of vector generation, analysis, editing, and map composition. Except for these, the 
United States Geological Survey's Digital Shoreline Analysis System (DSAS 5.0) software was used for cast transects and shoreline change calculations.

\subsection{Data Processing}

It is necessary to be pre-prepared satellite images before analysis. The geometric correction of all three images was done at first. Radiometric correction for each of the satellite image bands was then done. It includes two steps: first, to convert DN values into radiance values, then to convert the radiance values into reflectance. The Landsat MSS image of 1978 was considered the base map for the entire study and was resampled in $30 \mathrm{~m}$ to match the Landsat TM, ETM+, and OLI images in spatial resolution.

\subsection{Shoreline Extraction}

Land or water bodies can be discriminated automatically by the selected threshold value that is appropriate to the average reflectance of the LULC types - the equation which is followed to discriminate given below (Finch, 1997).

$$
\boldsymbol{T}=\boldsymbol{P}_{W}\left(\boldsymbol{R}_{W}+\boldsymbol{R}_{I c}\right)
$$

Where,

$$
\begin{aligned}
& \mathrm{T}=\text { Threshold } \\
& P_{W}=\text { The fraction of the pixel which water is the Land cover type } \\
& R_{W}=\text { Average Reflectance from the water in the infrared wavelength } \\
& R_{I C}=\text { Average Reflectance from the land cover in the infrared wavelength }
\end{aligned}
$$

From the equation, a pixel can be defined as water if

$$
\boldsymbol{P}_{W} \boldsymbol{R}_{W}+\left(\mathbf{1}-\boldsymbol{P}_{W}\right) \boldsymbol{R}_{I c}<T
$$

It can also be classified as non- water

$$
\boldsymbol{P}_{W} \boldsymbol{R}_{W}+\left(\mathbf{1}-\boldsymbol{P}_{W}\right) \boldsymbol{R}_{I c}>T
$$

Land and water interface are clearly visible, and shorelines can be easily demarcated. Then shoreline pixels were extracted, and the image used to be transformed into a binary image. Finally, the raster binary image used to be transformed into a vector image, and the shoreline boundary was extracted that is presented in Figure 3. 


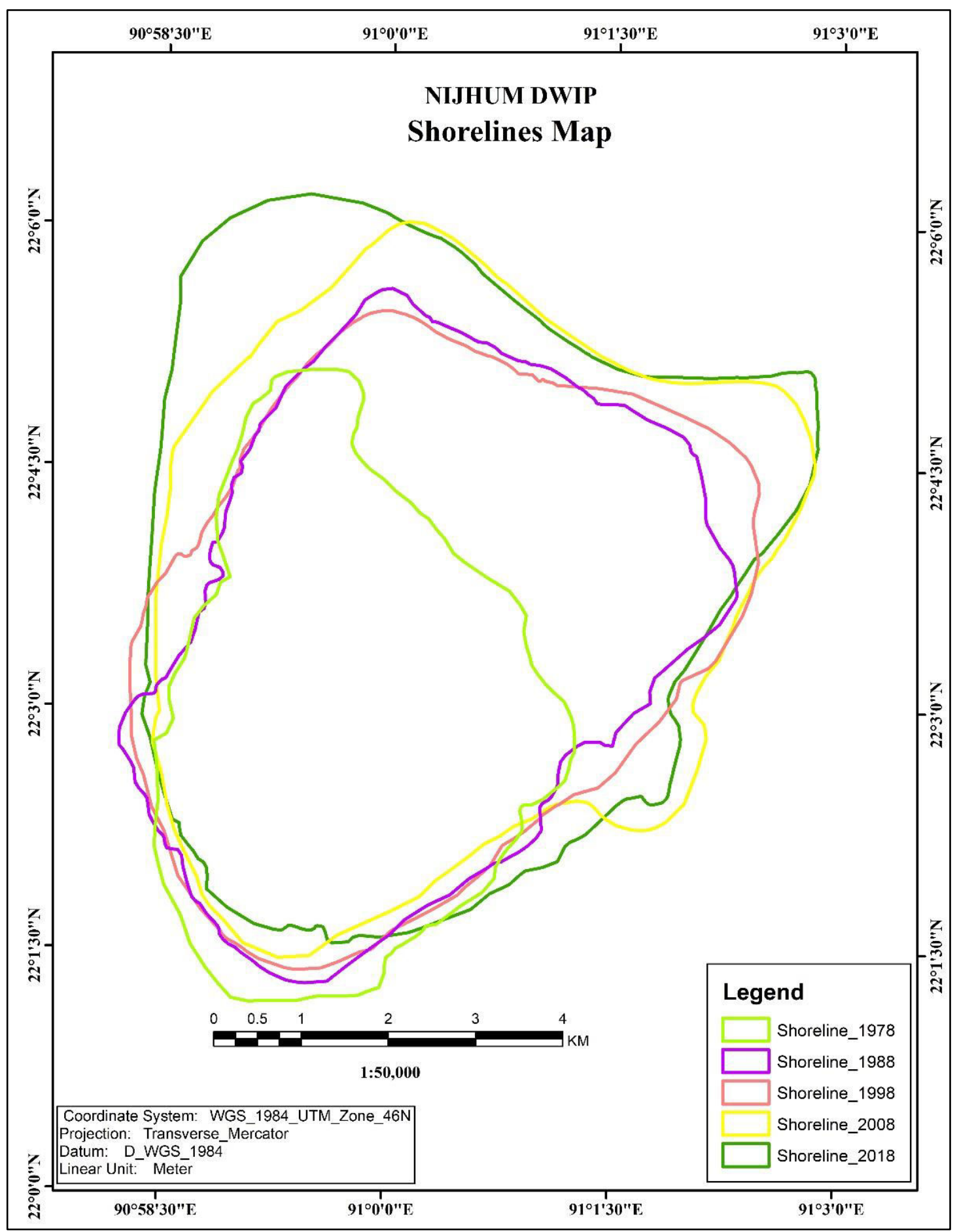

[Data Source: NASA LP DAAC,1978,1988,1998,2008,2018]

Figure 3: Various periods Shorelines of the Study Area 


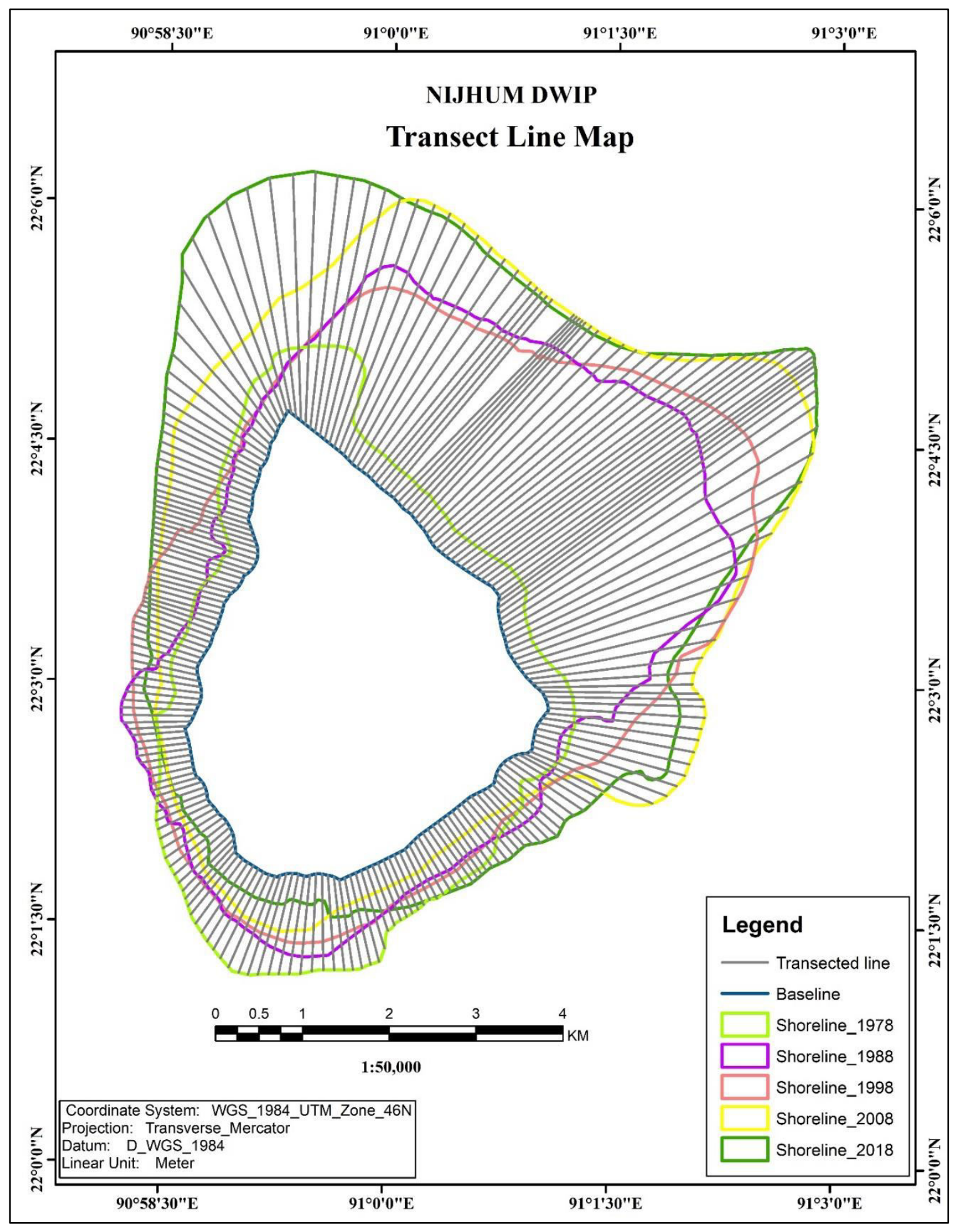

Figure 4: Transected line from baseline

Data Source: NASA LP DAAC,1978,1988,1998,2008,2018] 


\subsection{Shoreline Change Calculations and Prediction}

To identify the shoreline change, first exerted a baseline and converted shorelines into a feature class. We then used the 'digital shoreline analysis system' (DSAS) version 5 (Thieler, et al., 2017) to generate the transect line (Figure 4). With the help of this software, first, the transect line exerted 214 segments with $70 \mathrm{~m}$ intervals of shorelines of the study area that are divided. After that calculated net shoreline movement by following this formula (Thieler, et al., 2017)

\section{Net Shoreline Movement = Distance Between Oldest and newest Shoreline}

And to find out changing rate, the calculated endpoint rate (EPR) (Thieler, et al., 2017)

\section{End Point rate $=$ Distance in meters $/$ Time bewteen Oldest and most recent Shoreline}

Shoreline prediction can determine by Several models have been evaluated for shoreline prediction with the help of historical data such as the End Point Rate (EPR) model (Fenster, et al., 1993), Average of Rates (AOR), Linear Regression (LR) and Jackknife model (JK) (Dolan, et al., 1991), etc. The EPR model is a simple function used here for estimating the change in shoreline position concerning the rate of change over a period of time (Fenster, et al., 1993) and data regarding sediment transport and wave action are not required (Li, et al., 2001).

The EPR model predicts the shoreline with the rate of movement of the shoreline (slope), time interval, and intercept.

\section{Shoreline Position $=$ Slope $\times$ Time intervel + Intercept}

The initial $\left(Y_{1}\right)$ and end positions $\left(Y_{2}\right)$ are extracted from the images which are used by the EPR. This is the predicted shoreline, mEPR. $\mathrm{Y}$ is the rate of change in the shoreline, $\mathrm{X}$ represents the time interval, and $\mathrm{B}$ is the intercept.

$$
\bar{Y}=m E P R * X+B_{E P R}
$$

mEPR is calculated for the set of samples a

$$
\operatorname{mEPR}=\left(Y_{1}-Y_{2}\right) /\left(X_{2}-X_{1}\right)
$$

The intercept

$$
B_{E P R}=Y_{1}-\left(m E P R * X_{1}\right)=Y_{2}-\left(m E P R * X_{2}\right)
$$


The line is extended beyond the most recent point $(\mathrm{t})$, hence shoreline position equation can be represented using the position $Y_{2}$ and elapsed time $\left(X_{t}-X_{1}\right)$ as

$$
Y_{t}=m E P R *\left(X_{t}-X_{2}\right)+Y_{2}
$$

\subsubsection{Model Validation}

First derived 2018 shoreline prediction as to the same steps of shoreline prediction, the result has been validated with the 2018 shoreline using 65 GCPs from a ground survey. The RMSE (Root Mean Square Error) is calculated as

$$
R M S E=\left[n^{-1 \sum_{i=1}^{n}\left(X_{M O D}-X_{O R G}\right)^{2}-\left(Y_{M O D}-Y_{O R G}\right)^{2}}\right]^{\frac{1}{2}}
$$

$X_{O R G}$ and $Y_{O R G}$ are the original $\mathrm{X}$ and $\mathrm{Y}$ coordinates and $X_{M O D}$ and $Y_{M O D}$ are the generated value of the mode. It is estimated that the range of error in actual and model generates shoreline from 0 to $992 \mathrm{~m}$. the average error is $281 \mathrm{~m}$ and RMSE calculated as $16.76 \mathrm{~m}$.

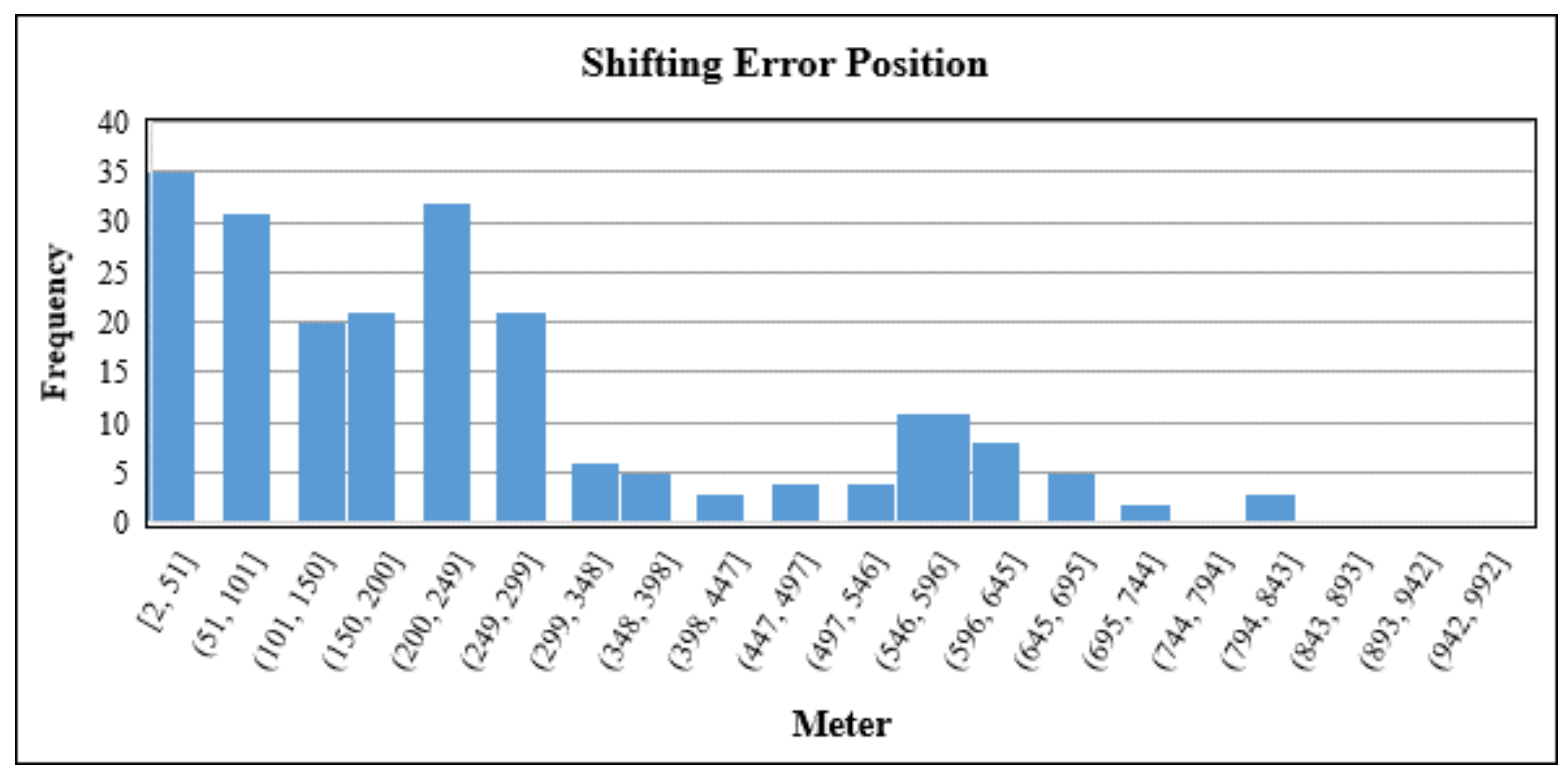

Figure 5: Shift in Position of Actual and Predict Shoreline

\subsubsection{Error Adjustment}

After RMSE calculation, the error in the shoreline needed to generate models, and finally, the future shoreline was adjusted. 


\subsection{Erosion-Accretion Rate Calculation}

The followed formula to extract the NDWI where the range is -1 to +1 and a positive value represents water body, whereas negative values show land (McFeeters, 1996).

$$
N D W I=(G R E E N-N I R) /(G R E E N+N I R)
$$

After extracted NDWI images, classified those into two categories, likely land and water-based on a positive and negative value. Then classified, used 'raster to polygon' tool to converted raster image into polygon shapefile. With the help of 'erase' and 'intersect' tool, which overlay layer, determine the erosion accretion and unchanged area throughout the study area.

\subsection{LULC Change analysis}

After geo-correction is done, the Raster calculator tool is used to determine the NDVI value.

$$
N D V I=(N I R-R E D) /(N I R+R E D)
$$

The range of NDVI value is -1 to +1 . The extreme negative values show water body, near around zero value, represents bare soil and over 0.4 represent green Vegetation, mangrove Vegetation, etc. which is used to classified various land use and land cover class - then used 'raster to polygon' tool to converted raster image into polygon shapefile.

\section{RESULTS}

\subsection{Shoreline Change Calculations}

The shoreline is the boundary between land and water that is continuously changed by natural processes or anthropogenic activities. Natural processes included wave characteristics, circulation of water near the seashore, geomorphological formation, characteristics of sedimentation, channel shifting, geotectonic change, etc. Anthropogenic activities included sand mining, resource extraction in the coastal belt, etc. The area of shoreline was changed by the erosion- accretion process.

\subsubsection{Length of Shoreline}

The area and perimeter measurements for 1978, 1988, 1998, 2008, and 2018 were calculated to determine the changes in the length of the shoreline and area of Nijhum Dwip (Table 3). The length of the shoreline of the study area was $19.81 \mathrm{~km}$ in 1978 that increased about $27.18 \mathrm{~km}$ in 
2018. But the shorelines don't increase evenly every year. Along with the area of the study area was 2237 hectares in 1978 that increased with time to about 4565.94 hectares in 2018.

\begin{tabular}{|c|c|c|c|c|c|}
\hline Year & $\mathbf{1 9 7 8}$ & $\mathbf{1 9 8 8}$ & $\mathbf{1 9 9 8}$ & $\mathbf{2 0 0 8}$ & $\mathbf{2 0 1 8}$ \\
\hline Length (in km) & 19.81 & 23.49 & 22.89 & 25.8 & 27.18 \\
\hline $\begin{array}{c}\text { Study Area (in } \\
\text { Ha) }\end{array}$ & 2237 & 3339.77 & 3580.45 & 4195.85 & 4565.94 \\
\hline
\end{tabular}

\section{Table 3: Length of Shoreline}

The layer of 1978, 1988, 1998, 2008, and 2018 were overlaid for the spatial detection of areas increased-decreased and erosion-accretion. The values obtained from the overlay analysis of 1978-1988, 1988-1998, 1998-2008, and 2008-2018 are presented in Table 4. The length of shoreline increased by $37.18 \%$ of 1978's length from 1978 to 2018 . The highest increased was observed in 1978-1988 (18.55\% of 1978's length). The shoreline also decreased in 1988-1998 (2.5\% of 1988's length) and then continues to increase 12.7\% of 1998's length in 1998-2008 and $5.32 \%$ of 2008 's length between $2008-2018$ periods. Besides that, the area of study area increased 104.11\% of 1978's area from 1978-2018 periods. The highest increased area was observed from 1978 to 1988 (49.29\% of 1978's area). The lowest increased area was observed in $1988-1998$ (7.2\% of 1988's area). It is also found that the study area is continuously increased. The analysis revealed that, with an increase of $7.37 \mathrm{~km}$ shoreline, the study area had gained about 2328.95 hectares of land. The result is found because of the deposition of silt (Sattar, S A; Mutsaers, H J W, 2004).

It is estimated from the analysis that the accretion rate is very high in the study area, and the erosion rate is comparatively low in the study area. The greatest accretion was much higher, about 1288.29 hectares, and the greatest erosion much slower about 185.52 hectares in the year 1978 to 1988 , whereas the unchanged area, remains about 2051.48 hectares.

\begin{tabular}{cccccc}
\hline Year & $\mathbf{1 9 7 8 - 1 9 8 8}$ & $\begin{array}{c}\mathbf{1 9 8 8}- \\
\mathbf{1 9 9 8}\end{array}$ & $\begin{array}{c}\mathbf{1 9 9 8} \\
\mathbf{2 0 0 8}\end{array}$ & $\mathbf{2 0 0 8 - 2 0 1 8}$ & $\mathbf{1 9 7 8 - 2 0 1 8}$ \\
\hline Accretion (Hectares) & 1288.29 & 461.87 & 989.02 & 607.86 & 2565.96 \\
\hline Erosion (Hectares) & 185.52 & 221.19 & 373.62 & 237.77 & 237.09 \\
\hline Unchanged (Hectares) & 2051.48 & 3118.58 & 3206.83 & 3958.08 & 1999.106 \\
\hline Gain/Loss (Hectares) & 1102.77 & 240.68 & 615.4 & 370.09 & 2324.87 \\
\hline Shoreline Changed & 18.55 & -2.5 & 12.69 & 5.32 & 37.18 \\
\hline
\end{tabular}




\begin{tabular}{cccccc}
\hline $\boldsymbol{( \% )}$ & & & & & \\
\hline Area Changed (\%) & 49.30 & 7.21 & 17.19 & 8.82 & 104.11 \\
\hline
\end{tabular}

Table 4: Land Area Changed of the Study Area

From 1988 to 1998, the accretion rate was much slower, while only 461.87 hectares of land was raised, and the unchanged area remains about 3118.58 hectares. The amount of eroded land was 221.19 hectares in that period. In the next ten years (1998-2008) the accretion rate was higher (989.02 hectares), and about 3206 hectares land was unchanged. The eroded rate was much higher (373.62 hectares) than the previous ten years. From the year 2008 to 2018, the accretion rate was about 607.86 hectares, and about 237.77 hectares areas were found in an unchanged condition. And the amount of eroded land was 237.77 hectares. Period considers 1978 to 1988; the deposition rate was higher.

Consequently, it almost gained 1102.77 hectares of land. After that, this area lost 0.59 hectares of land in the year between 1988 to 1998 period. In the next ten years (1998-2008), the study area gained 33.68 hectares of land. Between the 2008-2018 period, it gained almost 370 hectares.

\subsubsection{Net Shoreline Movement}

The net shoreline movement (NSM) is the distance between the oldest and the youngest shorelines for each transect. To find out, the trend of shoreline shifting, calculated net shoreline movement (NSM). The spatial distribution of NSM between 1978 to 2018 is presented in Figure 6, and the graph of Figure 7 compares the result of NSM for the different sections of the study area. For this study, used 214 segments at 75 meters intervals. From those segments, 161 shows positive shifting, and 53 shows negative shifting. The highest positive movement is 4272.2 meters, and the highest negative movement is (-) 884.03 meters. The highest positive movement found on the northern side (section-2) of the study area. And the highest negative movement found on the Southern side (section-4). The range of movement towards the sea is-155 meters to 1781.9 meters at the western side (section-1),1870. 85meters to 4267.2 meters at the Northern side (section-2), -1.17meters to 2726.29 meters eastern side (section-3) of the study area. The movement of the landward movement is only at the southern side (section-4) of the study area ($884.03 m--30.24)$. 


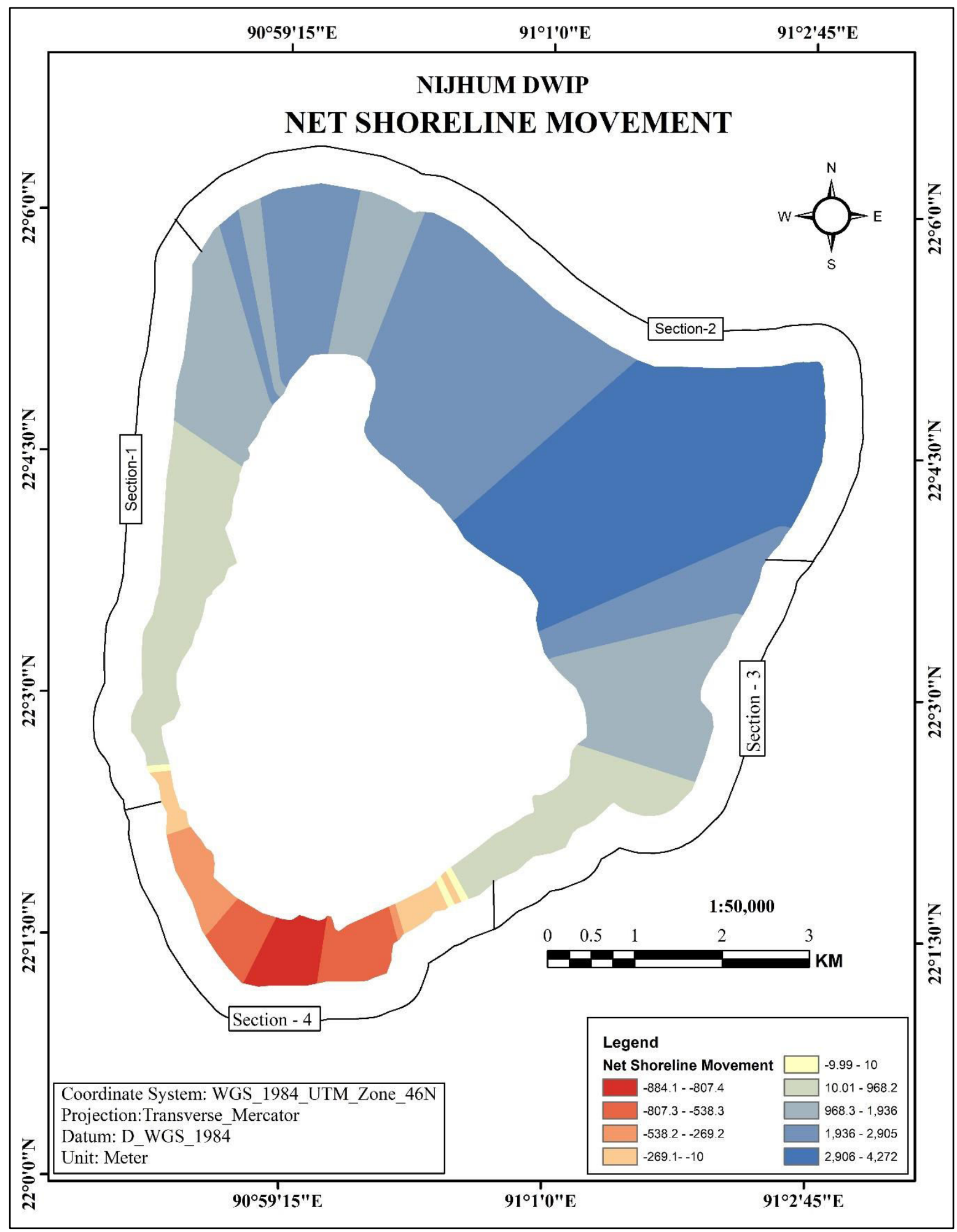

[Data Source: NASA LP DAAC,1978,1988,1998,2008,2018]

Figure 6: Net Shoreline Movement of the Study Area 


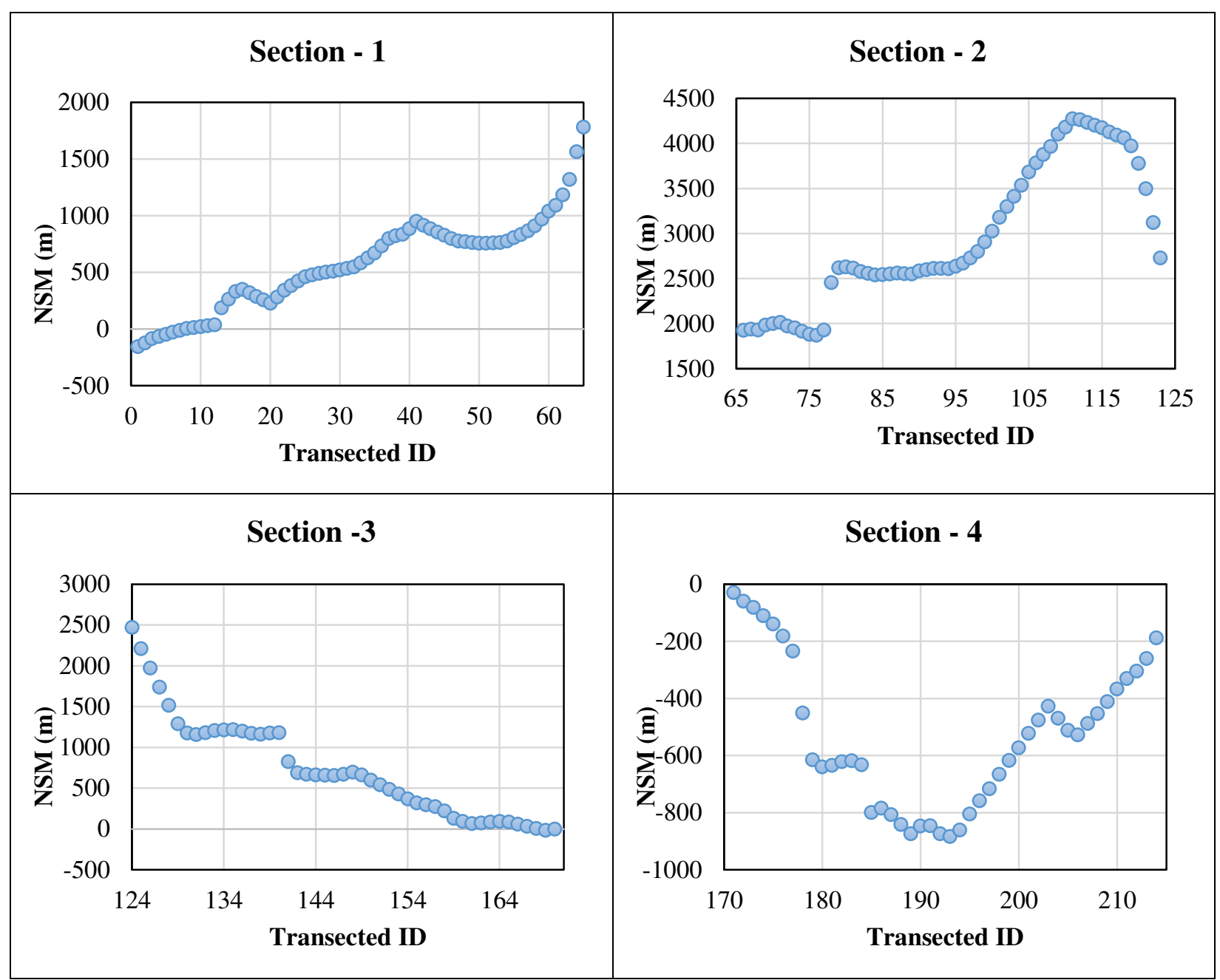

Figure 7: Section Wise NSM

\subsubsection{End Point Rate}

To find out the short-term shoreline shifting, also calculated Endpoint rate (EPR). EPR helped to find out the movement direction (either towards the sea or inland). Positives value indicated the movement towards the sea, and a negative value indicates the movement towards the land. The spatial distribution of EPR between 1978 to 2018 is presented in Figure 8, and the graph of Figure 9 compares the result of EPR for a different section of the study area. From this analysis, it has been found that the shifting rate at the Western side (section-1), northern side (section-2), eastern side (section-3) are positive and the ranges are $-3.87 \mathrm{~m}$ to $44.55 \mathrm{~m}$ per year, $46.77 \mathrm{~m}$ to $106.81 \mathrm{~m}$ per year and $-0.47 \mathrm{~m}$ to $61.7 \mathrm{~m}$ per year respectively. But the shifting rate at the southern side (section-4) of the study area is negative, and the range is $-22.1 \mathrm{~m}$ to $-0.76 \mathrm{~m}$ per year. 


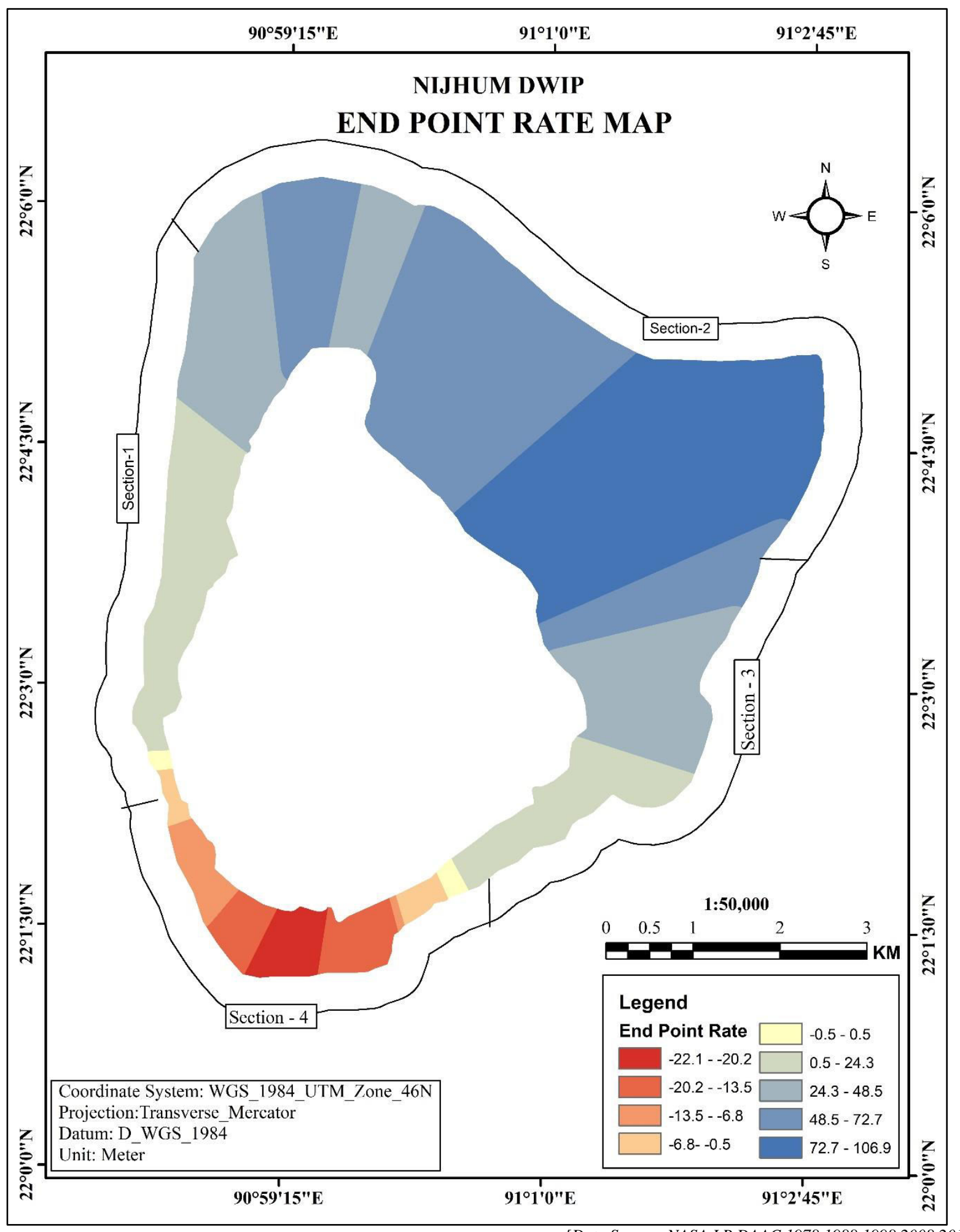

[Data Source: NASA LP DAAC,1978,1988,1998,2008,2018]

Figure 8: End Point Rate of the Study Area. 


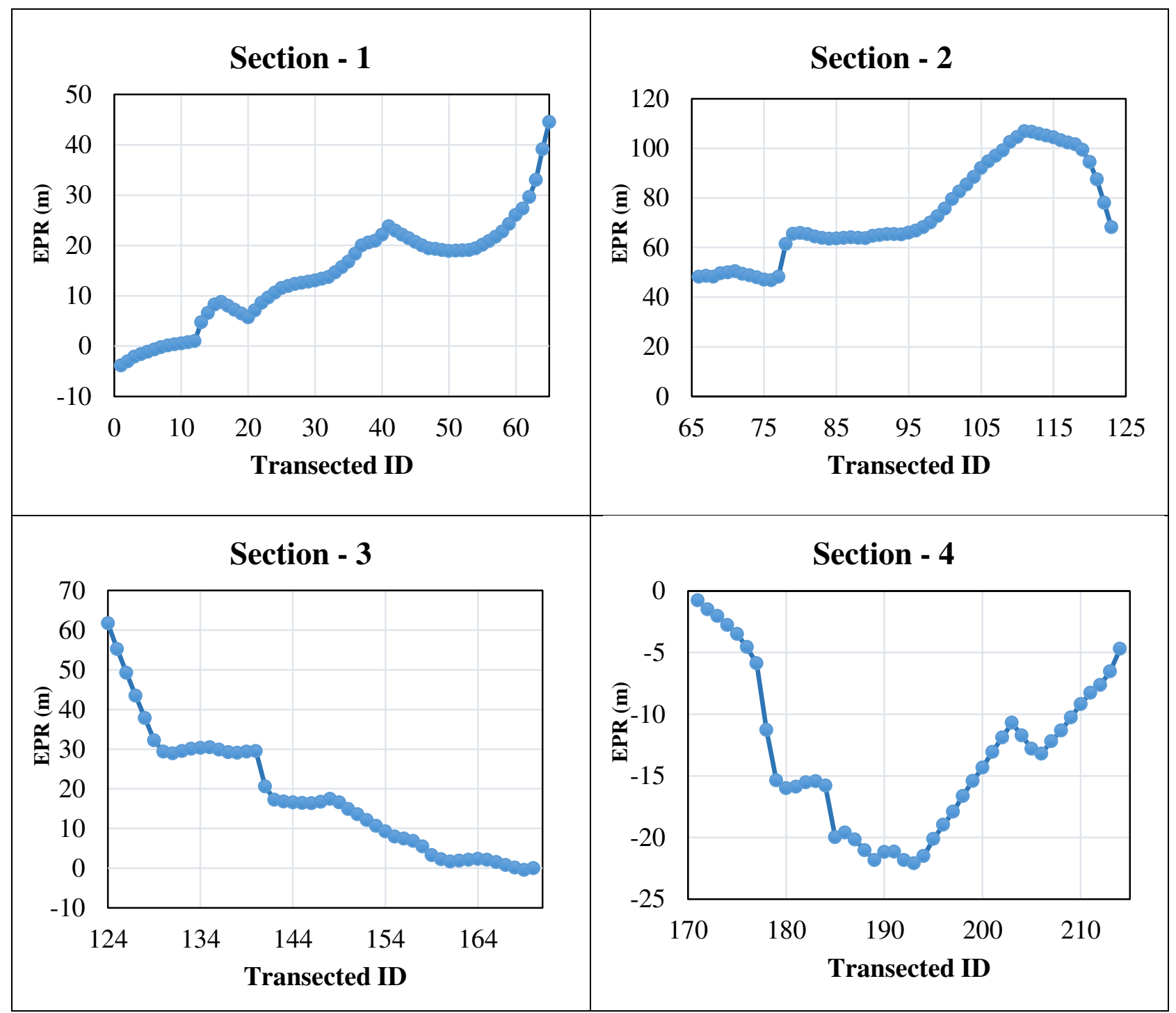

Figure 9: Section Wise EPR

\subsubsection{Shifting Pattern of Shoreline}

From the analysis of the spatial shifting pattern of the study area is presented in Figure 10. it is found that the deposition rate was much higher at the northern side (Section-2), and the pattern also was shifted towards both the western (section-1) and eastern (section-3) side. From 1978 to 2018, the northern side accretion rate was high (35.48 hectares per year) and the western side accretion rate was 7.42 hectares per year because of high discharge of Meghna River (Jakobsen, et al., 2000) that trend to the north to south (figure 11) and very low velocity (Salek, et al., 2001). Erosion mainly occurred on the southern side (section-4) was about 4.69 hectares per year from 
1978 to 2018 due to a direct fraction of waves and currents. And it is observed from Figure 11 that the eastern side of the study area also started to erode because of forming meandering. So, this analysis suggested that land extended towards the North West side of the study area and erosion will be occurred on the southern side, also slightly on the northern and western side.

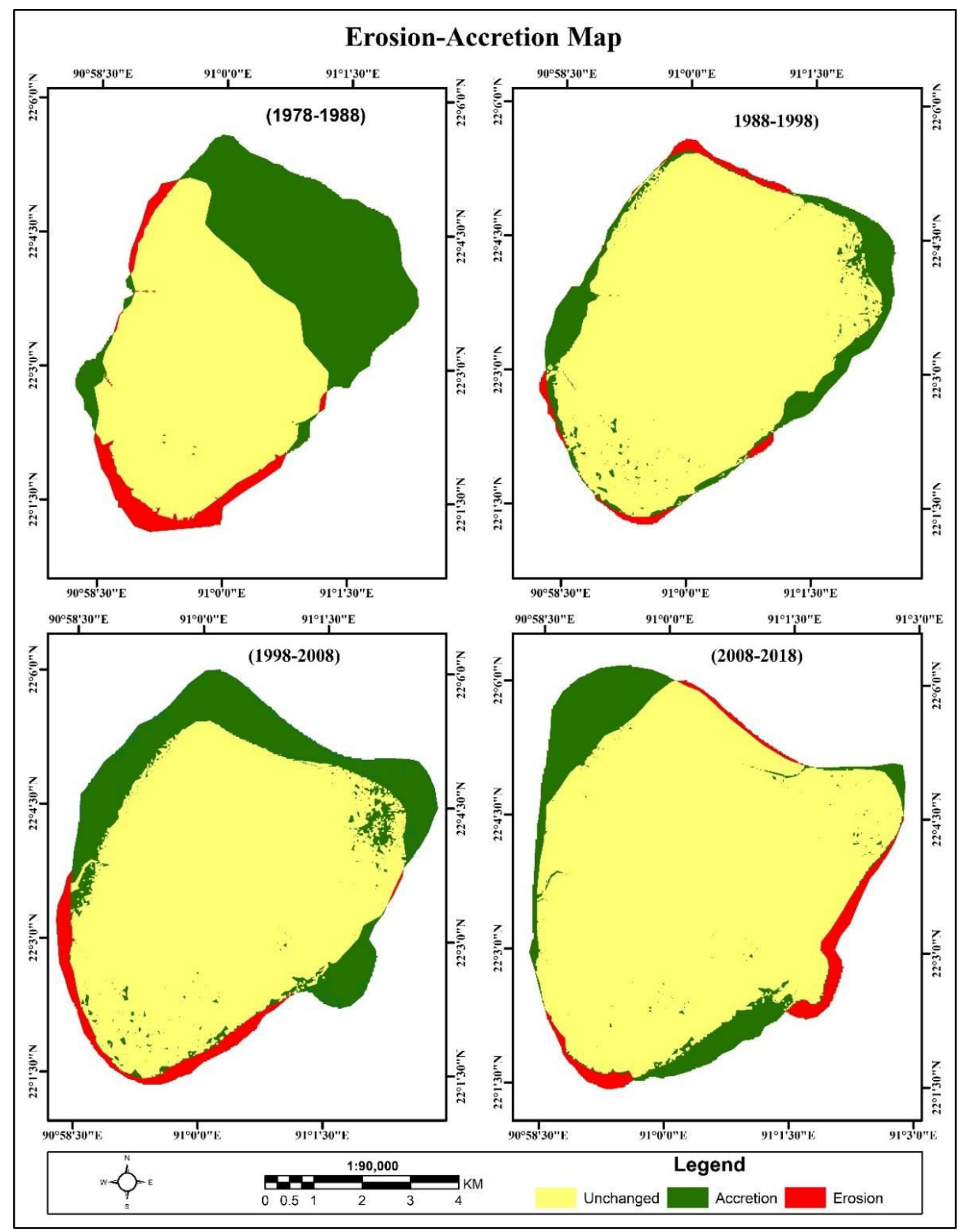

Figure 10: Erosion Accretion on the Study Area 


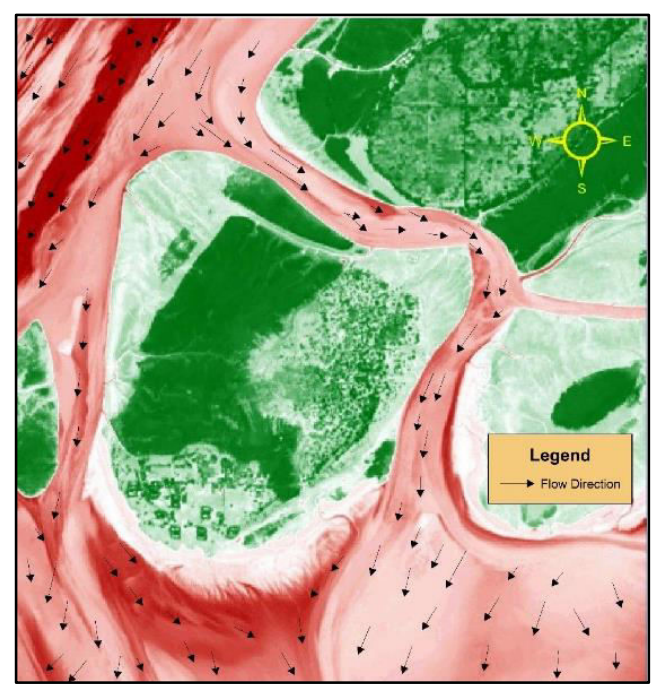

Figure 11: Meander of Channel

[Data Source: GEBCO gridded data, 2019]

\subsubsection{Shoreline prediction}

From the analysis of prediction by the EPR model, after that error adjustment, the shoreline of 2028 is derived in Figure 12(a). The length of shoreline will be increased by 29.38 kilometers, and the total area will be increased by 5210.26 hectares in 2028. Erosion will occur in 87.37 hectares, and accretion will occur in 731.69 hectares in 2028. Also, the Unchanged area will remain 4478.57 hectares and Net gain areas will 644.32 hectares (Figure12(b))

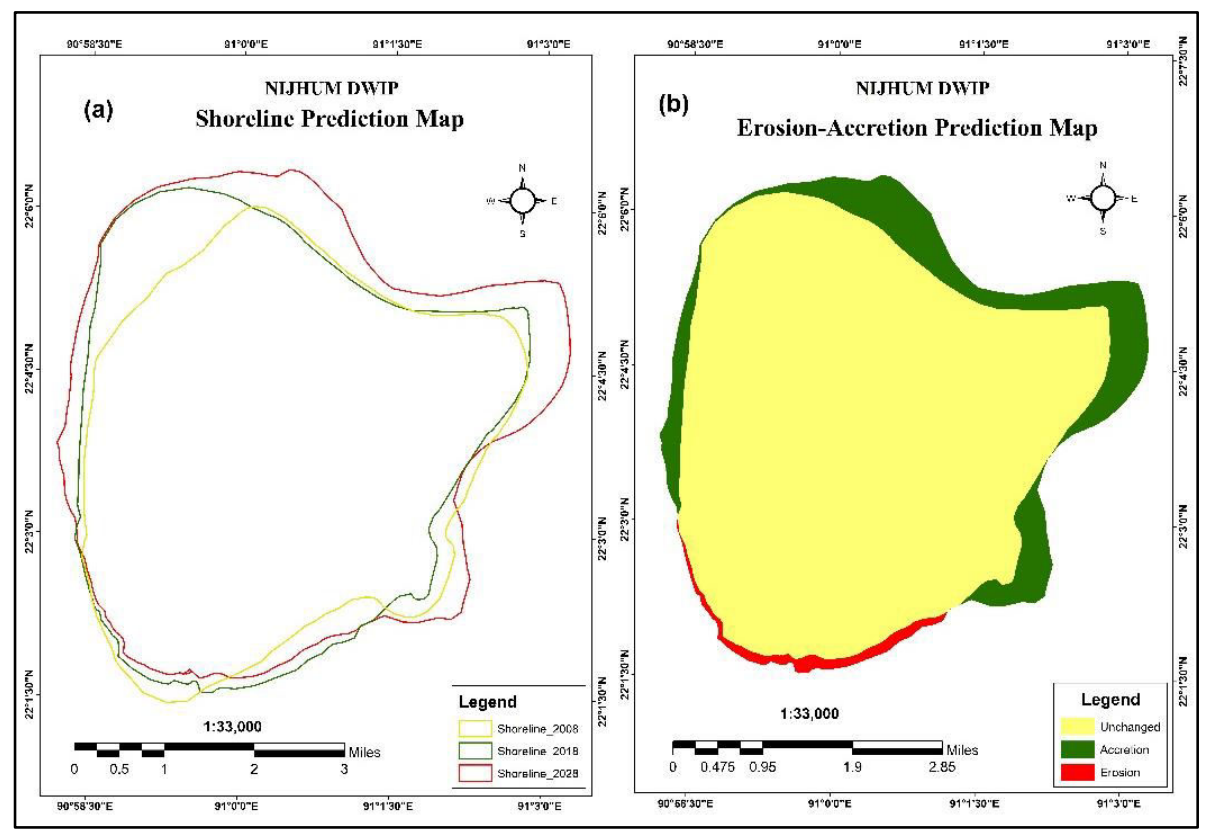

[Data Source: NASA LP DAAC, 1978, 1988, 1998, 2008, 2018]

Figure 12(a): Prediction of Shoreline (2028) and 12(b): Prediction of Erosion-Accretion 


\subsection{Vegetation Changes due to Shoreline Shifting}

The vegetation pattern of the study area observed a huge change over five decades. Due to natural calamities, government involvement in various types of plantation programs and deforestation of native people for using forest resources as fuel and fish catcher stick. The main aim of this section to estimate LULC change based on geomorphic units as barren land (sandy beach), mudflats and vegetation units as homestead vegetation, grassland, cropland, green vegetation due to shoreline shifting

\subsubsection{Land use and Land cover Pattern}

By the pre-classification of the NDVI image (Figure 14), Land Use and Land Cover areal calculation were implemented in Table 5 and Figure 13. And the trend of increased- decreased is presented in Table 5.2. The total vegetated area was 2233.83 hectares in 1978. After that, it was increased from 1978-1988, 1998-2008, and 2008-2018 but decreased to about 2.97 hectares from 1988 to 1998 .Total $99.69 \%$ increase of 1978's total vegetated area between 1978-2018 periods.

Mangrove vegetation was covering more portions every year in the study area. About $0.63 \%$ was barren land, $0.75 \%$ was mudflat, $18.91 \%$ was homestead vegetation, and $19.64 \%$ was grassland, $8.37 \%$ was cropland, $6.72 \%$ was green vegetation, and $44.04 \%$ was mangrove vegetation drastically of its total area at 2018.

\begin{tabular}{cccccc}
\hline Classification/year & $\mathbf{1 9 7 8}$ & $\mathbf{1 9 8 8}$ & $\mathbf{1 9 9 8}$ & $\mathbf{2 0 0 8}$ & $\mathbf{2 0 1 8}$ \\
\hline Barren Land & & 8.96 & 0.54 & 26.08 & 28.96 \\
\hline Mudflat & 2.39 & 30.24 & 4.48 & 99.14 & 34.10 \\
\hline Homestead Vegetation & 108.16 & 153.05 & 132.53 & 497.03 & 863.57 \\
\hline Grassland & 308.44 & 330.71 & 523.72 & 365.11 & 896.83 \\
\hline Crop Land & 471.04 & 200.11 & 403.96 & 758.36 & 382.32 \\
\hline Green Vegetation & 358.29 & 131.74 & 168.90 & 485.48 & 306.95 \\
\hline Mangrove Vegetation & 987.90 & 2459.61 & 2343.14 & 1905.96 & 2011.23 \\
\hline Total vegetated area & 2233.83 & 3275.22 & 3272.25 & 4011.94 & 4460.89 \\
\hline
\end{tabular}

Table 5: Land use Land Cover Area (ha) of the Study Area

According to the analysis, it revealed that mudflat, homestead vegetation, grassland, cropland, green vegetation, mangrove vegetation was $0.11 \%, 4.84 \%, 13.8 \%, 21.06 \%, 16.01 \%, 44.16 \%$ drastically its total area respectively in 1978 and there is no barren land in 1978. That about $0.27 \%$ barren land, $0.91 \%$ mudflat, $4.58 \%$ homestead vegetation, $9.9 \%$ grassland, $5.99 \%$ 
cropland, 3.94\% green vegetation, $73.65 \%$ mangrove forest drastically of its total area at 1988that involves highest mangrove vegetation part. Further in the study area, drastically $0.01 \%$ barren land, $0.13 \%$ mudflat, $3.7 \%$ homestead vegetation, $14.62 \%$ grassland, $11.28 \%$ cropland, $4.71 \%$ green vegetation, $65.44 \%$ mangrove vegetation of its total area at 1998. Drastically of its total area barren land, mudflat, homestead vegetation, grassland, cropland, green vegetation, mangrove vegetation $0.62 \%, 2.36 \%, 11.84 \%, 8.7 \%, 18.07 \%, 11.57 \%, 45.42 \%$ at 2008 respectively that also involves the highest mudflat. Highest homestead vegetation and grassland found in 2018.

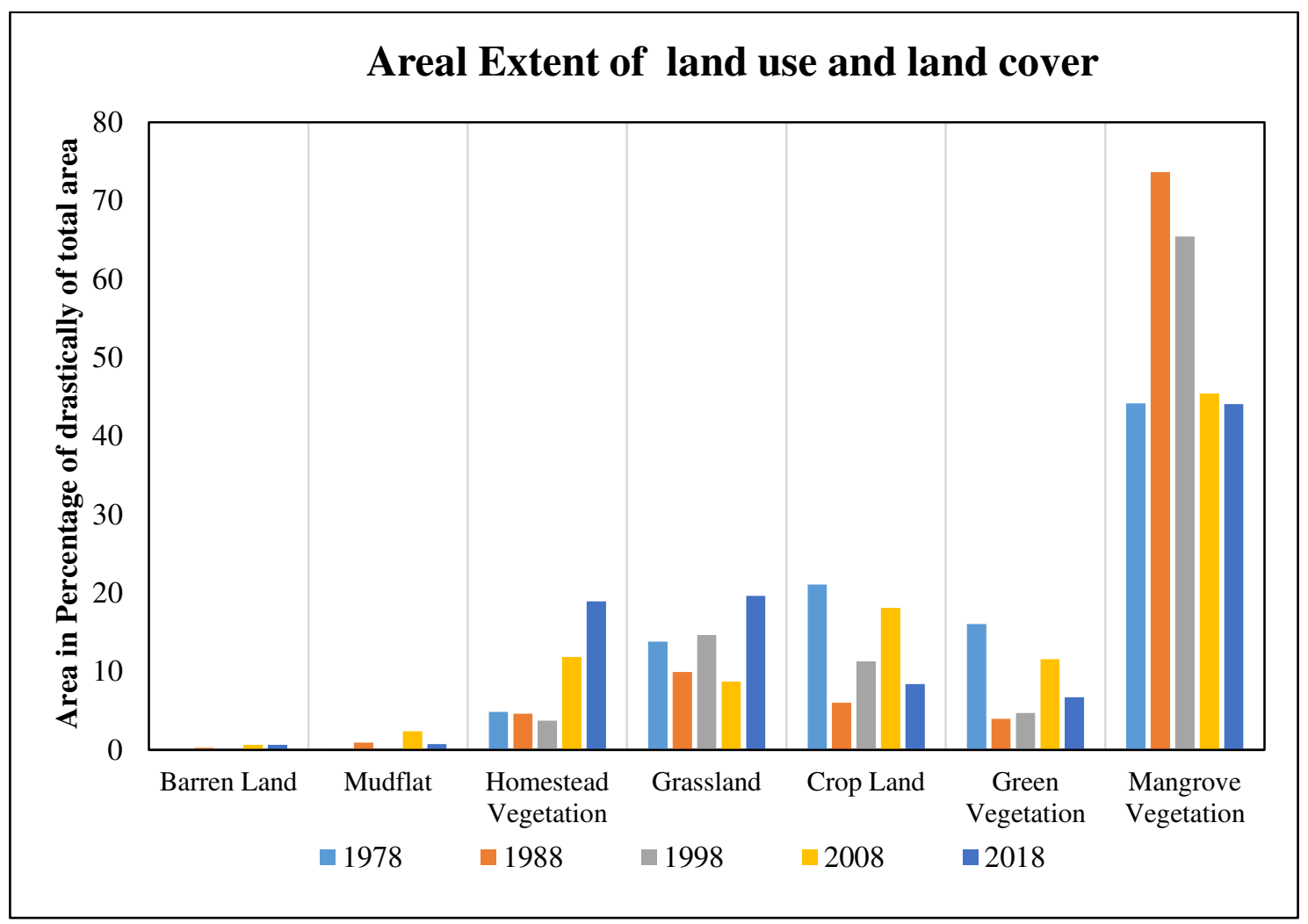

[Data Source: NASA LP DAAC, 1978, 1988, 1998, 2008, 2018]

Figure 13: Land Use and land Cover area of Different Class (Period 1978-2018) 


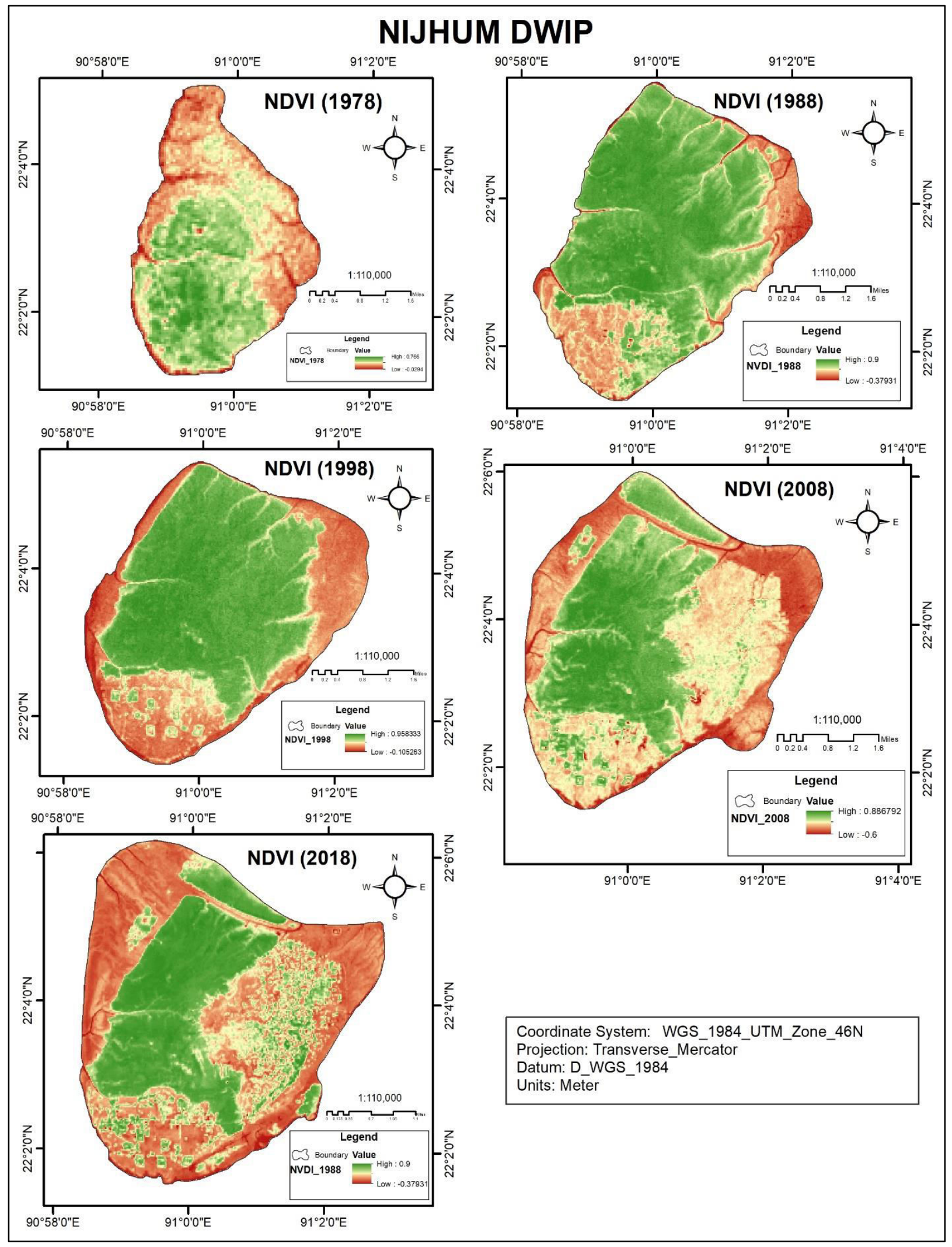

[Data Source: NASA LP DAAC, 1978, 1988, 1998, 2008, 2018]

Figure 14: Vegetation Map 


\begin{tabular}{cccccc}
\hline Classification & $\begin{array}{l}\mathbf{1 9 7 8}- \\
\mathbf{1 9 8 8}\end{array}$ & $\begin{array}{l}\mathbf{1 9 8 8}- \\
\mathbf{1 9 9 8}\end{array}$ & $\begin{array}{l}\mathbf{1 9 9 8}- \\
\mathbf{2 0 0 8}\end{array}$ & $\begin{array}{c}\mathbf{2 0 0 8}- \\
\mathbf{2 0 1 8}\end{array}$ & $\begin{array}{c}\mathbf{1 9 7 8}- \\
\mathbf{2 0 1 8}\end{array}$ \\
\hline Barren Land & 0.27 & -0.25 & 0.60 & 0.01 & 0.63 \\
\hline Mudflat & 0.79 & -0.78 & 2.24 & -1.62 & 0.64 \\
\hline $\begin{array}{c}\text { Homestead } \\
\text { Vegetation }\end{array}$ & -0.25 & -0.88 & 8.14 & 7.07 & 14.08 \\
\hline Grassland & -3.89 & 4.73 & -5.93 & 10.94 & 5.85 \\
\hline Crop Land & -15.07 & 5.29 & 6.79 & -9.70 & -12.68 \\
\hline Green Vegetation & -12.07 & 0.77 & 6.85 & -4.85 & -9.29 \\
\hline $\begin{array}{c}\text { Mangrove } \\
\text { Vegetation }\end{array}$ & 29.48 & -8.20 & -20.02 & -1.38 & -0.11 \\
\hline
\end{tabular}

[Data Source: NASA LP DAAC, 1978, 1988, 1998, 2008, 2018]

Table 6: Change of Land Use and Land Cover (\%)

From table 6, it is noticed that in the last 50 years, barren land (sandy beach) was increased by $0.63 \%$ drastically in its total area. The highest increased in barren land (0.60 \%) in 1998-2008. Mudflat was increased $0.64 \%$ drastically of its total area in 1978-2018 periods. Mudflats mainly showed unstable characteristics, as it is continuously increased-decreased with the time interval. Homestead vegetation increased drastically in its total area was about $14.08 \%$ between the 1978 to 2018 periods. The highest increased in Homestead vegetation was 8.14\% (364.5 ha) in 19982008. About $6.30 \%$ of grassland drastically of its total area increased in the last five decades. In 2008-2018, grassland also increased at a high rate was 36.654 hectares per year (10.94 $\%$ drastically of its total area). On the contrary, cropland and green vegetation drastically of its total area decrease from about $12.68 \%$ and about $9.29 \%$ respectively between 1978 to 2018 periods. From 1978 to 1988, cropland and green vegetation were decreases in high amounts (drastically of its total area of $15.07 \%$ and $12.07 \%$ respectively) because of governmental plantation programs. And mangrove forests increased $29.48 \%$ in $1978-1988$, but it is an inclination to decrease now from 1988 to 2018. The highest decreased (20.02\%) in 1998-2008. Mangrove vegetation increased in 1978-1988 due to plantation programs in 1974.

\subsubsection{Land use and Land cover Changes}

Land use and Land cover statistics resulting from NDVI classification of 1978 and 2018 showed that there was no barren land in the initial stage that refers to no unchanged barren land. Moreover, $12.13 \%$ of initial mudflats converted into the final barren land, and $0.61 \%$ of accreted 
land changed into barren land. Barren land was increased by $0.93 \%$ of initial mangrove vegetation and $0.43 \%$ of initial green vegetation on the southern side, which is dominated by erosional activities.

\begin{tabular}{|c|c|c|c|c|c|c|c|c|c|c|c|}
\hline & & & \multicolumn{9}{|c|}{ Final Stage } \\
\hline & & & \multicolumn{8}{|c|}{ Stable Area } & \multirow{2}{*}{ 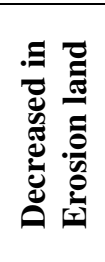 } \\
\hline & & & 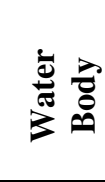 & 氙 & $\sum_{\sum}^{\stackrel{n}{E}}$ & 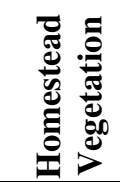 & 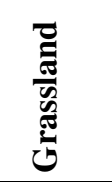 & $\frac{\vec{\Xi}}{\frac{\pi}{0}}$ & 离 & 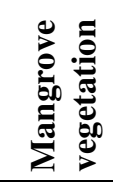 & \\
\hline \multirow{7}{*}{ 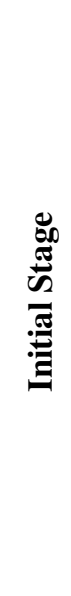 } & \multirow{6}{*}{ 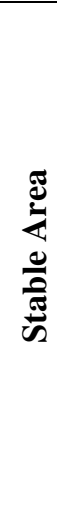 } & Mudflats & 0.00 & 0.29 & 0.00 & 0.01 & 0.06 & 0 & 0.09 & 0.43 & 1.51 \\
\hline & & $\begin{array}{l}\text { Homestead } \\
\text { Vegetation }\end{array}$ & 0.00 & 2.03 & 0.16 & 11.74 & 17.41 & 10.30 & 9.92 & 35.02 & 21.58 \\
\hline & & Grassland & 0.27 & 0.35 & 0.76 & 18.89 & 43.98 & 33.12 & 20.96 & 173.21 & 16.9 \\
\hline & & Crop land & 0.20 & 0.08 & 1.06 & 16.58 & 46.93 & 36.06 & 32.71 & 318.15 & 19.27 \\
\hline & & $\begin{array}{c}\text { Green } \\
\text { Vegetation }\end{array}$ & 0.07 & 1.55 & 2.44 & 13.94 & 38.45 & 30.80 & 33.06 & 196.69 & 41.29 \\
\hline & & $\begin{array}{l}\text { Mangrove } \\
\text { vegetation }\end{array}$ & 0.33 & 9.15 & 12.49 & 112.73 & 171.83 & 68.24 & 56.93 & 419.64 & 136.86 \\
\hline & \multicolumn{2}{|c|}{$\begin{array}{l}\text { Increased in } \\
\text { Accreted land }\end{array}$} & 41.12 & 15.51 & 17.19 & 689.68 & 578.17 & 203.81 & 153.27 & 846.08 & \\
\hline
\end{tabular}

Table 7: Change Matrix of Land Use and Land Cover from 1978 to 2018 (ha)

There were no mudflats that also remain unchanged from the initial stage. Mudflats mostly increased from mangrove vegetation (1.26\% of initial mangrove vegetation) and accretion activities $(0.68 \%$ of accreted land) as various cannel was formed in a new area for drainage water. Likewise, $63.18 \%$ of initial mud flat decreases by erosional activities.

Around $10.85 \%$ of initial homestead vegetation (1978) remains the same in the final state. The highest chance of homestead vegetation occurred on accreted land, about $27.10 \%$ of accreted land. However, $11.41 \%$ of initial mangrove vegetation cover turned into homestead vegetation. Deforestation activities are responsible for this depletion of mangrove forests in which homestead vegetation was increased. On the contrary, homestead vegetation decreased $19.95 \%$ of 1978's homestead vegetation, which results from erosional activities.

About $22.72 \%$ of initial grassland were grown on new bare soil along the seashore, which is accreted, and about $5.48 \%$ of initial grassland were decreased by erosion. Similarly, $17.39 \%$ of 
initial mangrove vegetation cover was turned into final grassland and unchanged remain $14.26 \%$ of initial grassland from periods 1978 to 2018. And about $10.73 \%$ of initial green vegetation converted into grassland.

Also, it is observed that about cropland increased $9.52 \%$ of initial homestead vegetation, and $10.74 \%$ of initial grassland turned into final stage cropland. About $7.66 \%$ of initial cropland was unchanged in the final stage. With many anthropogenic activate, a total of $8.59 \%$ of initial green vegetation converted into cropland between 1978 to 2018 period. Nevertheless, with an increasing new land, cropland was not increased with proper proportion because of the high soil salinity of soil and proper irrigation problem. And $4.09 \%$ of initial cropland decreased due to erosion.

It is observed that $9.23 \%$ of initial green vegetation was static in the final stage. Green vegetation mostly destroyed on the southern side due to erosion of about $11.52 \%$ of initial green vegetation loss. Also, $6.02 \%$ of accreted land turned into green vegetation.

\begin{tabular}{|c|c|c|c|c|c|c|c|c|c|c|}
\hline & & \multicolumn{9}{|c|}{ Final Stage } \\
\hline & & 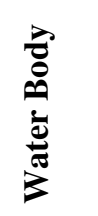 & 䄊 & 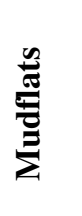 & 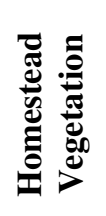 & 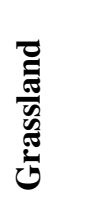 & $\frac{\bar{\Xi}}{\frac{\pi}{2}}$ & 总 & 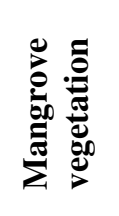 & 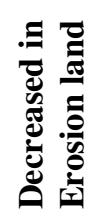 \\
\hline \multirow{7}{*}{ 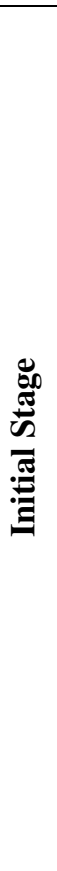 } & Mudflats & 0 & $\begin{array}{c}12.1 \\
3\end{array}$ & 0 & 0.42 & 2.51 & 0 & 3.77 & 17.99 & 63.18 \\
\hline & Homestead Vegetation & 0 & 1.88 & $\begin{array}{c}0.1 \\
5\end{array}$ & $\begin{array}{c}10.8 \\
5\end{array}$ & $\begin{array}{c}16.2 \\
0\end{array}$ & 9.52 & 9.17 & 32.38 & 19.95 \\
\hline & Grassland & 0.09 & 0.11 & $\begin{array}{c}0.2 \\
5\end{array}$ & 6.12 & $\begin{array}{c}14.2 \\
6\end{array}$ & $\begin{array}{c}10.7 \\
4\end{array}$ & 6.80 & 56.16 & 5.48 \\
\hline & Crop land & 0.04 & 0.02 & $\begin{array}{c}0.2 \\
3\end{array}$ & 3.52 & 9.96 & 7.66 & 6.94 & 67.54 & 4.09 \\
\hline & Green Vegetation & 0.02 & 0.43 & $\begin{array}{c}0.6 \\
8\end{array}$ & 3.89 & $\begin{array}{c}10.7 \\
3\end{array}$ & 8.59 & 9.23 & 54.89 & 11.52 \\
\hline & Mangrove vegetation & 0.03 & 0.93 & $\begin{array}{c}1.2 \\
6\end{array}$ & $\begin{array}{c}11.4 \\
1\end{array}$ & $\begin{array}{c}17.3 \\
9\end{array}$ & 6.91 & 5.76 & 42.47 & 13.85 \\
\hline & Increased in Accreted land & 1.62 & 0.61 & $\begin{array}{c}0.6 \\
8\end{array}$ & $\begin{array}{c}27.1 \\
0\end{array}$ & $\begin{array}{c}22.7 \\
2\end{array}$ & 8.01 & 6.02 & 33.25 & \\
\hline
\end{tabular}

Table 8: Change Matrix of Land Use and Land Cover from 1978 to 2018 (\%) 
On the contrary, $13.85 \%$ of initial mangrove vegetation loss by erosion, where around $42.47 \%$ of initial mangrove vegetation remains unchanged in the final stage. About $33.25 \%$ of accreted land is converted into final mangrove vegetation.

\subsubsection{Accuracy Assessment}

An accuracy assessment was conducted to verify the quality and reliability of the classification exercise. From RGB=754 band and google, Erath image was stacking, and 65 points were taken for accuracy assessment. At 2018 overall accuracy is $81.54 \%$ with kappa co-efficient is $0.78>$ 0.7 (Table: 9) that is strong enough (Forkuo \& Frimpong, 2012).

\begin{tabular}{cccccc}
\hline Year & $\mathbf{1 9 7 8}$ & $\mathbf{1 9 8 8}$ & $\mathbf{1 9 9 8}$ & $\mathbf{2 0 0 8}$ & $\mathbf{2 0 1 8}$ \\
\hline Overall accuracy & $83.22 \%$ & $81.13 \%$ & $79.83 \%$ & 86.85 & 81.54 \\
\hline Kappa co-efficient & 0.79 & 0.8 & 0.81 & 0.82 & 0.78 \\
\hline
\end{tabular}

[Data Source: NASA LP DAAC, 1978, 1988, 1998, 2008, 2018]

Table 9: Accuracy Assessment Table

\subsubsection{Shoreline with Vegetation Changes}

It is noticed that shoreline increased $7.63 \mathrm{~km}(37.18 \%)$ and vegetated area 2227.06hectares (99.6\%) from 1978-2018. The highest increased of shoreline and vegetation land about $3.67 \mathrm{~km}$ (18.54\%) and 1041.39 hectares (46.62\%), respectively, in 1978-1988. Again, shoreline and vegetated land decreased about $0.59 \mathrm{~km}(2.5 \%)$ and 2.79 hectares $(0.09 \%)$, respectively, in 19881998. After that, shoreline increased with increasing vegetated land, that means in proportion.

From the statistical analysis, the Pearson correlation coefficient is positive and the significant value is 0.997 , which means a strong relation of shore length with the vegetated area. From the regression analysis, the $\mathrm{R}$ square value is 0.994 , which indicates the vegetated area is strongly dependent on shore lengths. One km shoreline changes with 298.007 hectors vegetated area.

\begin{tabular}{|c|c|c|c|}
\hline \multicolumn{2}{|c|}{} & Shore length $(\mathbf{k m})$ & $\begin{array}{c}\text { Vegetated area } \\
\text { (ha) }\end{array}$ \\
\hline \multirow{3}{*}{$\begin{array}{c}\text { Shore length } \\
(\mathbf{k m})\end{array}$} & Pearson Correlation & 1 & .997 \\
\cline { 2 - 4 } & Sig. (2-tailed) & & .000 \\
\cline { 2 - 4 } & $\mathrm{N}$ & 5 & 5 \\
\hline \multirow{2}{*}{$\begin{array}{c}\text { Vegetated area } \\
(\text { ha) }\end{array}$} & Pearson Correlation & .997 & 1 \\
\cline { 2 - 4 } & Sig. (2-tailed) & .000 & 5 \\
\cline { 2 - 4 } & $\mathrm{N}$ & 5 & \\
\hline
\end{tabular}




\section{Table 9: Correlation between Shore Length and Vegetation Changes}

In 2028, Shore length will be increased by $29.38 \mathrm{~km}$ that encourage vegetated area, which will increase in 5103.39 hectares.

\begin{tabular}{|c|c|c|c|c|c|c|c|c|}
\hline & \multicolumn{2}{|c|}{$\begin{array}{c}\text { Unstandardized } \\
\text { Coefficients }\end{array}$} & \multirow{2}{*}{$\begin{array}{c}\text { Standardized } \\
\text { Coefficients }\end{array}$} & \multirow[t]{2}{*}{$\mathrm{t}$} & \multirow[t]{2}{*}{ Sig. } & \multicolumn{2}{|c|}{$\begin{array}{l}95.0 \% \text { Confidence } \\
\text { Interval for B }\end{array}$} \\
\hline & & B & $\begin{array}{c}\text { Std. } \\
\text { Error }\end{array}$ & & & & $\begin{array}{l}\text { Lower } \\
\text { Bound } \\
\end{array}$ & $\begin{array}{l}\text { Upper } \\
\text { Bound } \\
\end{array}$ \\
\hline \multirow[t]{2}{*}{1} & (Constant) & $\begin{array}{c}- \\
3652.054\end{array}$ & 312.570 & & -11.684 & 0.001 & 4646.793 & 2657.316 \\
\hline & $\begin{array}{c}\text { Shore length } \\
\text { (in km) }\end{array}$ & 298.007 & 13.040 & 0.997 & 22.853 & 0.000 & 256.507 & 339.507 \\
\hline \multicolumn{9}{|c|}{ a. Dependent Variable: Vegetated area (in ha) } \\
\hline
\end{tabular}

Table 10: Correlation of determinant, $\mathbf{R}^{2}$

\subsection{Socio-economic condition changes due to shoreline shifting}

People started living in this study area during 1969 (Rahman, 2010). Due to shoreline shifting, the socio-economic condition of the study area is always an unstable situation. Shoreline position change means erosion accretion is promoted displacement of human livelihood. In the study, the accretion rate was high as various socio-economic elements were diversifying from their past situation. For this study, responses were collected through a questionnaire survey from 397 native people and authority members.

\subsubsection{Migration Scenario}

From the figure 15, there is no out-migration occurred rather in migration. About $86 \%$ of people migrated here in the 1978-2018 periods. In the last 30-40 years ago, the percentage of migration is $38 \%$, when the shore area accreted highly. The reason for this migration has been split into two categories: push and full factors. Push factors include riverbank erosion, environmental destruction. However, pull factors are working facilities, availability of new land, and the chance to live with the same classes people. It is noticed that some families migrate due to political issues and family quarrels. It is noted that this site is located close to the seashore, and from here,

\section{Pull factors for migration}

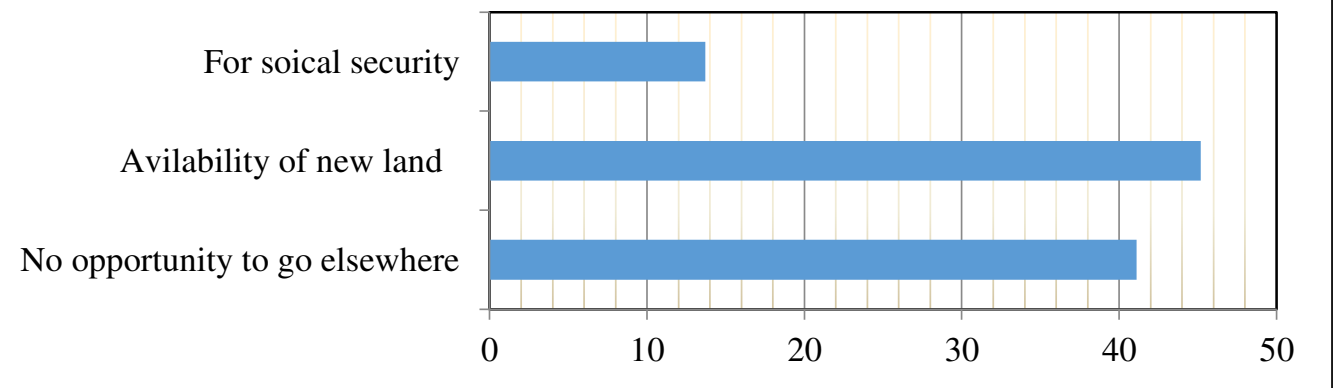


it is very simple to practice fishing. As with most individuals who are born here, they are fishermen.

\section{Figure 15: Migration Pull Factors}

[Source: Field Survey, 2019]

From the above analysis, the availability of new land is (45\% of migrated respondents) the main reason for migration in the study area. 


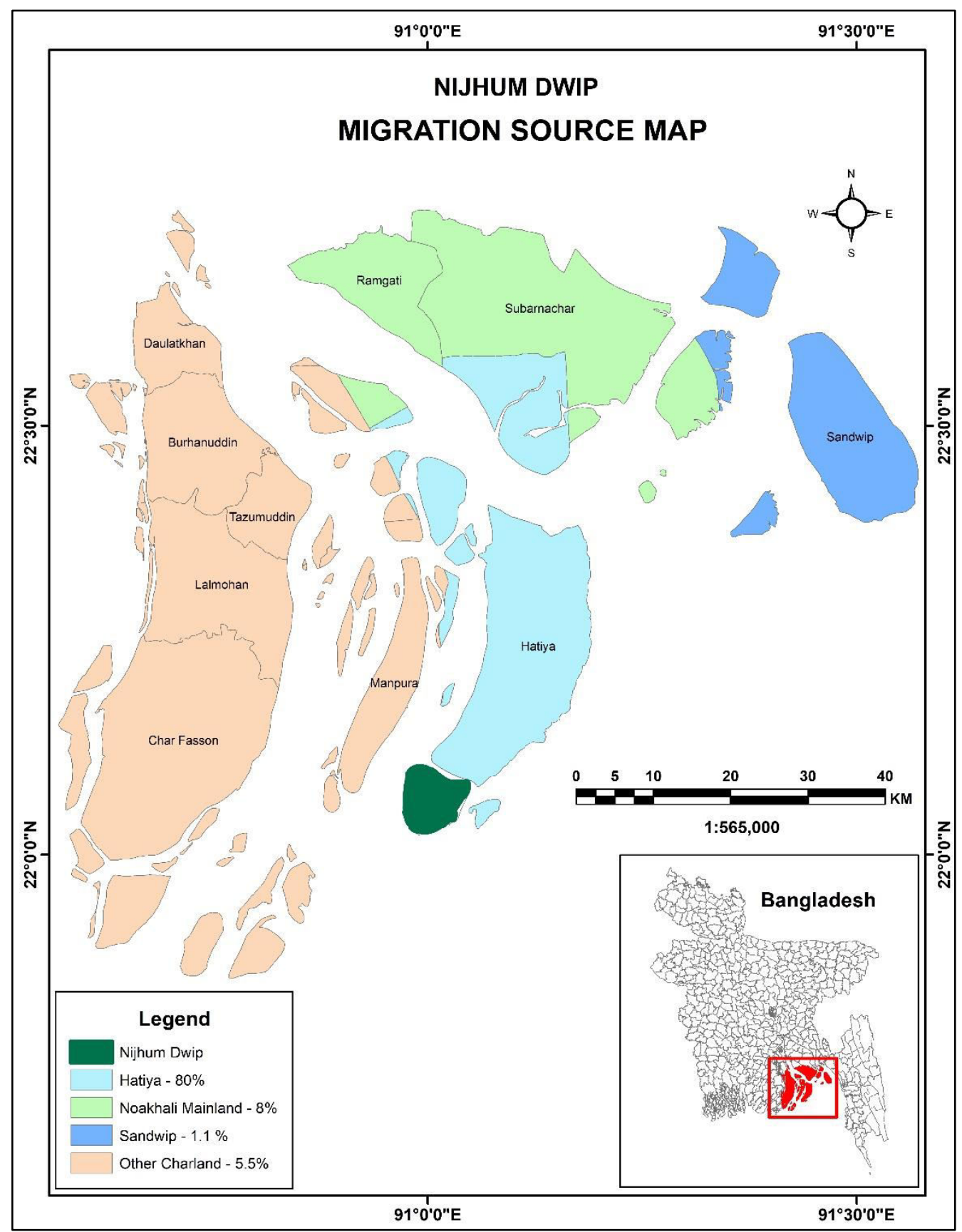

Figure 16: Origin of Migrated People

[Source: field survey, 2019]

About $80 \%$ of people migrated from Hatiya, 5.5\% from other char, $8 \%$ from Noakhali mainland, and $6.5 \%$ from other lands (Figure 16). Hatiya was eroded on its west southern part that forces to migrate to the study area. Asides, in the front of the seashore, new land rise that gives an opportunity to ledge this land from the authority at a very cheap rate and then owned the land by occupation formula (called Bondobasta). 


\subsubsection{Habitation Condition}

From the primary data, one-storied houses are found in $96 \%$ of the respondents in the study area. The other $4 \%$ have multi-storied houses. These types of the house mainly build by woods and tin is used as a roofing material.

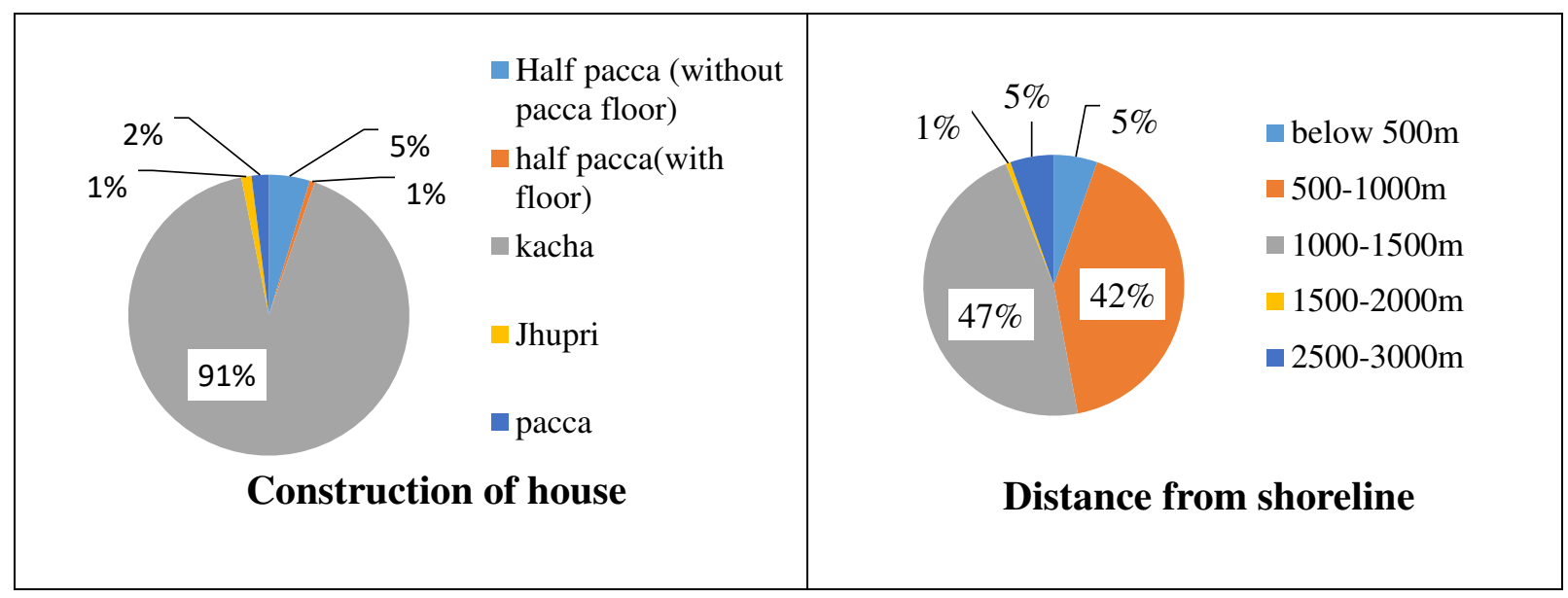

Figure 17 (a): Construction Materials and 17 (b): Distance from Shoreline

It is found that about $91 \%$ of participants have kacca houses (using mud and straw) that are set up by mangrove palm and tall reed. 5\% of participants have half-pacca houses, which made up of wood and tin without a floor. Respondents are like to build houses beside the seashore as their fisheries activities. So, they often made houses that can be easily moveable with the shoreline.

From Figure 17(b), about 47\% of respondents lived in 1-1.5 $\mathrm{km}$ from the shoreline from which most of them are kacha. Generally, permanent pacca house is built in stable land, which is accreted before that means minimum distance was created from the shoreline, and $42 \%$ of respondents lived in $0.5-1 \mathrm{~km}$ that they also move with shoreline because of the tidal effect that respondents made kaccha and Juphri house. If shoreline comes towards their land, tidal effects dampness is increased. That hampered their daily lifestyle.

\subsubsection{Economic condition}

It is obtained that the people in the study area mainly depend on fishing to live their daily livelihood. From figure 18, it is found that the percentage of fishers is $71 \%$, and $14 \%$ of people are farmers. This result shows that $87 \%$ of people depend on natural resources as the seashore. From these respondents, $86 \%$ of people were fishermen, and $7 \%$ were farmers before their current occupation. From this analysis, it is found that a total of $7 \%$ of farmers increase. Because 
of high salinity, farmers could only cultivate paddy, which has much salt tolerance. But in recent times, Low salinity area was increasing due to shore distance was increased. So, the farmer can practice more cropping agriculture than before. Also, the boatman was increased by $10 \%$ for serving the high population and tourist. And $1 \%$ of people are doing govt. Job, $4 \%$ labor, $5 \%$ businessman, $4 \%$ other includes driver, tourist guide, hotel manager, etc. That shows more variation in economic activities because the working fields are going rich than before.

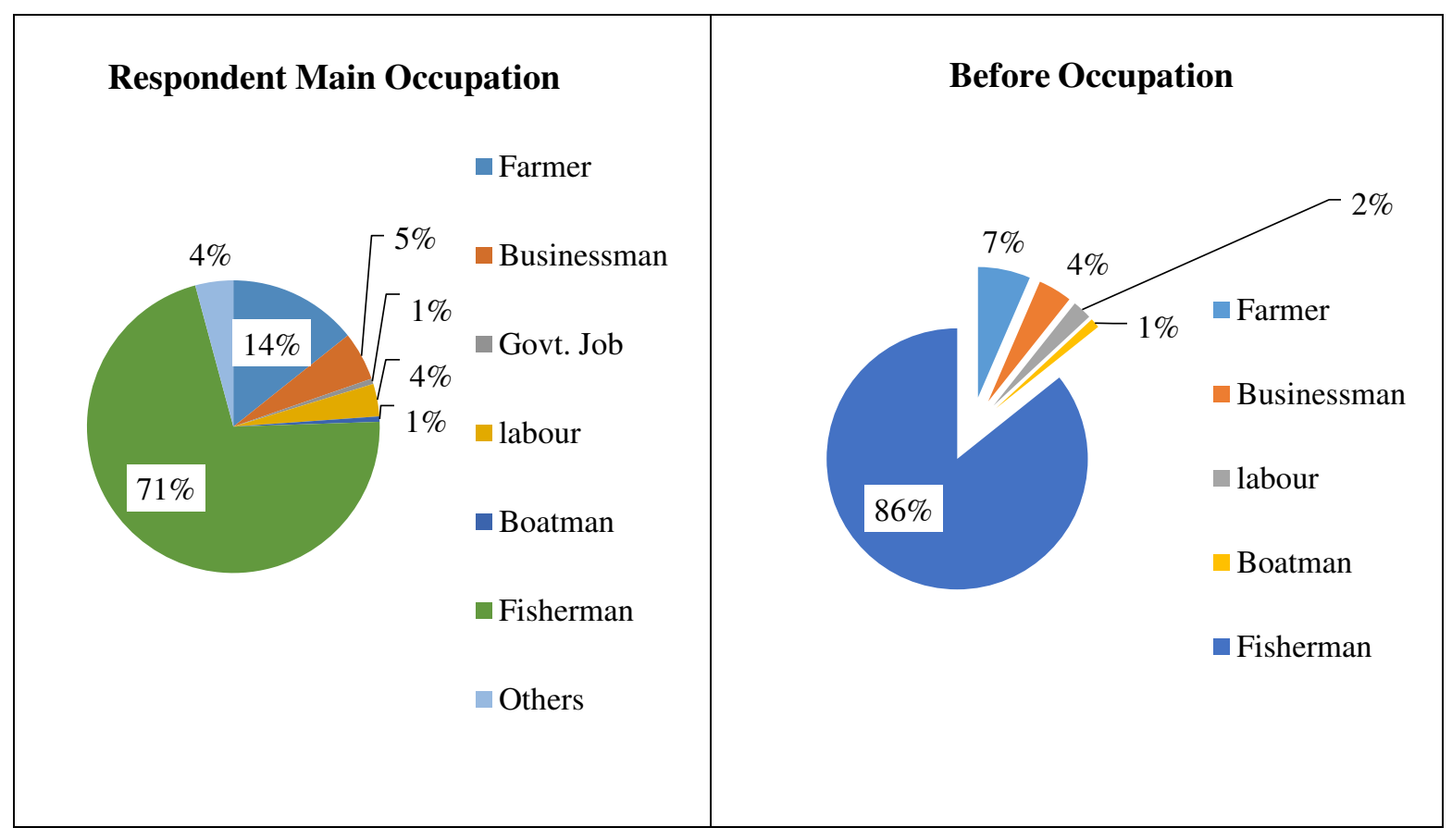

Figure 18: Occupation of Respondent

[Source: field survey, 2019]

Besides that, about $76 \%$ of people are involved in the second occupation. Among those people, $70 \%$ of people are adopting agriculture that respondents cultivated various vegetables to fulfill their family needs besides their main occupation, which can be only possible low salinity areas were increased. Also notice that $13 \%$ was labor, $5 \%$ was fisherman, $2 \%$ was boatman, and $1 \%$ businessman. They adopted the second occupation for extra income and also when fishers can't be able to catch fish for adverse climate and fish campaign time. Also, it is noticed that $9 \%$ of people are related to various economic activities such as tourist guides, driver, hotel manager, etc. 


\subsubsection{Tourism Condition}

Tourism in the study area is related to natural phenomena like a sandy beach, mangrove forest wildlife biodiversity: about $20 \mathrm{~km}$ sandy and grassy beach with mangroves forest which include spotted deer and unique bio-diversity. The tourism industry is developing over the year in the study area as well as throughout the country satisfied the respondent. According to all respondents, tourism activities in the study area have increased in the last decade.

\begin{tabular}{cccccc}
\hline Year & $\mathbf{1 9 7 8}$ & $\mathbf{1 9 8 8}$ & $\mathbf{1 9 9 8}$ & $\mathbf{2 0 0 8}$ & $\mathbf{2 0 1 8}$ \\
\hline $\begin{array}{c}\text { Wide of Moktaria channel } \\
(\mathbf{m})\end{array}$ & 3841 & 1675 & 1539 & 985 & 700 \\
\hline
\end{tabular}

[Data Source: NASA LP DAAC, 1978, 1988, 1998, 2008, 2018]

\section{Table 11: Distance from Hatiya.}

From table 11 shows the distance from the southern side of the Hatiya and the northern side of Nijhumdwip that is separated by the Moktaria Channel, which wide was decreasing due to high accretion at the northern side of the study area as about $70 \%$ of the tourist is from Hatiya and the mainland of Noakhali (from the primary survey) as increasing communication network.

Also, according to $96 \%$ of respondents, in the last decade, $83 \%$ of tourists who are mostly from the Noakhali district are traveled to the study area only for increasing sea beach, which is created by the erosion-accretion process.

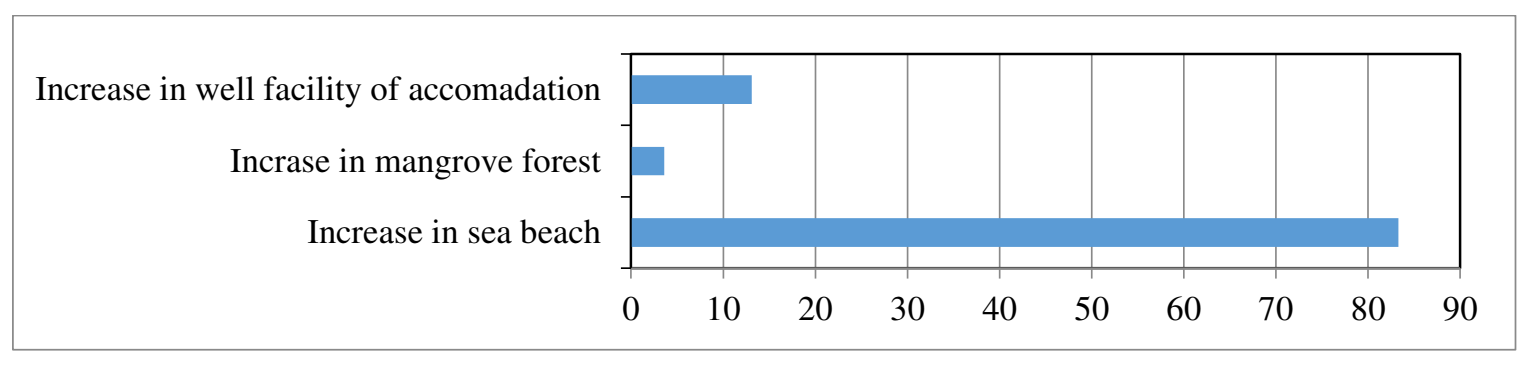

[Source: field survey, 2019]

\section{Figure 19: Reason for Increase in Tourist}

For increasing tourism activities, Socio-economic activates also improve. Such as man can switch their occupation, such as a tourist guide, infrastructure is increasing. Also, civilization facilities like road networks, electricity are increasing after declared Nijhum dwip as a tourism and entertainment spot by the Bangladesh government. 


\section{DISCUSSIONS}

The study showed the length of shoreline length is increased $37.18 \%(7.37 \mathrm{~km})$ from the period of 1978 to 2018 along with 104\% (2328.94 hectares) area increased. It is observed that the highest accretion has occurred (1288.29 hectares), and the highest erosion is observed (373.62 hectares) between the 1998 to 2008 periods. The average accretion rate was 51.33 hectares per year, and the average erosion rate was 4.74 hectares per year in 1978-2018. Through erosion and accretion happen every year in this study area, the unchanged area never decreases. It indicated that the landmass is increased. The net shoreline movement of the study area is seaward. Figure 10 shows that the movement is high in the north, north-western, and north-eastern part of the study area towards the sea. In the southern part, the movement is towards the inland. It is estimated that the rate of shoreline change is $-17 \mathrm{~m}$ to $86 \mathrm{~m}$ per year. The highest positive changing rate is found at the northern side ( $35 \mathrm{~m}$ to $86 \mathrm{~m}$ ).

The main reasons for shoreline shifting are increased sea level and erosion accretion. If the sea level rises, the shoreline decreases. Coastal erosion, together with rising sea-level with global warming, will displace millions of people from the coastal areas of Bangladesh in the 21st century (CDMP-II, 2014). Sea level was highest in 1998 (3360mm) when the shoreline was decreased $0.59 \mathrm{~m}$. And accretion occurred due to the high amount of discharge of the Meghna River and the low velocity of water flow. In future prediction shows that shore will increase 2.2 $\mathrm{km}$ from 2018 to 2028, and also area will increase 644.32 hectares. Erosion will be continuing on the southern side, and the rest of the sides will continue to accretion. The study exposes that most of the southern part of the study area is vulnerable to a high rate of shoreline erosion.

The result showed that barren land and was increased due to both erosion (in the southern side) and accretion activities. Mudflats were increased by erosion from mangrove and green vegetation. Grassland increased (22.72\% of final accreted land) in newly accreted land that means no near embankment. In the study area, plant succession was started from bear soil. It is called xerosere succession. In the early stage of xerosere, succession grasses are grown and then grew homestead vegetation like herbs. In addition, homestead vegetation land also was increased in accreted land in which human settlement increased as homestead vegetation and grassland were increased due to the accretion process. 
Cropland needs a proper irrigation system, but the distance from shoreline also increased from towards cropland due to accretion. As in the study area found only solar panel and generator for electricity supply which can't afford water pump for proper irrigation on cropland. So, when accretion occurred, the accessibility to water from the sea became more difficult for cultivation and cropland decrease. And accreted areas are high saline areas; as a result, some special types of crops can only be produced, which is high soil tolerance crops. Green vegetation, mangrove vegetation, and also a few croplands were decreased because of the increasing settlement area. About $11.52 \%$ of initial green vegetation decrease because of erosional activities. Also, the density of the population is responsible for decreasing mangrove forest because the large population needs more stable land for built habitation and wood for various activities as fire, khuti for fishing. Green vegetation also decreased into a settlement area as a human habitation. It is observed that shoreline decreased in 1998, on account of this total vegetated area also decreased (7.29 hectares). The shore length with vegetation has a very strong relationship in which significant value is 0.997 . Also, a vegetated area strongly depended on shore length that the $\mathrm{R}^{2}$ value is 0.994 . From the regression analysis, it is predicted that will 5103.39 hectares of the vegetated area, as well as shore length, will be $29.38 \mathrm{~km}$ in 2028.

The shoreline shifting also has an impact on the diversification of socio-economic conditions. Shore area increased that promoted $86 \%$ population migrate in the study area. Among this, $80 \%$ of respondents are from Hatiya Island, which is migrated to the study area due to the availability of new land $(46 \%)$. That with increasing shore area population was increasing that push to increasing land fragmentation. From the analysis, it is found that shoreline has a positive impact on population density. For a large population, habitation also builds that destroyed some vegetated areas. As a result, cropland, green vegetation, and mangrove forest are turned into human habitation areas and some of their purposive activities such as a pond. Most of the people are fishermen by born in the study area. About $71 \%$ of people are fishermen that they need to stay near to for their fish catching activities. The study area is dynamic in position as they didn't permanent their habitation. As a result, 91\% of respondents are made Jhupri that is easily moveable. Due to high accretion, their house distances from shore also increase, and some of their fishermen again shift their house near to shore. Figure 18 shows that the variation of economic activities is more than before. New fields create in newly accreted land such as market place increased is responsible for the increase in the business sector, road increased is also 
responsible for increasing driver and tourist guide more than before. That the study indicates, shore area has a positive impact on economic activities. Besides, for increasing tourism activities, which are increase mainly for seeing the beach and $2 \%$ permanent infrastructure is built for tourism, which is occurred because of erosional activities that represent increasing sandy beach and of accretion activities that represent increasing grassy beach.

Table 12: Interaction Matrix for Shoreline Activities with LULC and Social Unit

\begin{tabular}{|c|c|c|c|c|c|c|c|c|c|c|c|}
\hline & \multicolumn{7}{|c|}{ LULC unit } & \multicolumn{4}{|c|}{ Social unit } \\
\hline & 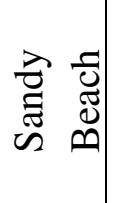 & 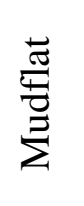 & 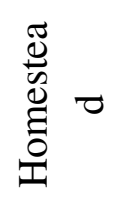 & 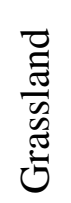 & 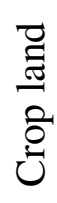 & 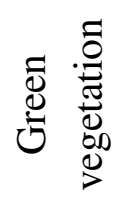 & 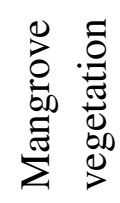 & 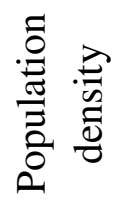 & $\begin{array}{l}\stackrel{\Xi}{\Xi} \\
\stackrel{\Xi}{\Xi} \\
\underset{\Xi}{\Xi} \\
\Xi\end{array}$ & 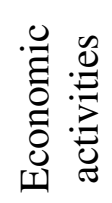 & 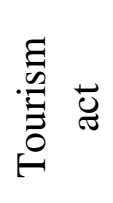 \\
\hline Erosion & + & - & & & & - & + & & & + & + \\
\hline Accretion & + & ++ & + & + & - & & & + & + & + & + \\
\hline $\begin{array}{l}\text { Density of } \\
\text { population }\end{array}$ & & & & & - & - & - & & & & \\
\hline
\end{tabular}

(+) Positive impacts, (-) Negative impacts

\section{CONCLUSIONS}

The morphological changes of the coastal zones of Bangladesh become a major social, economic, and environmental concern. Hence it requires immediate national policy attention, coordinated research, and action on the ground. Change in the shoreline of Nijhum Dwip has been studied here, which indicates a seaward shift of the shoreline. There has been a large increase in the total area of the island due to this change. Constant accretion is seen throughout a period of 50 years from 1978 to 2018. The study area is frequently affected by erosion-accretion because of its geographical position about a 104\% increase in its total landmass. Erosion occurred due to sea-level rise, and accretion occurred due to the high amount of discharge. The shoreline shifting has positive impacts on barren land (sandy beach), mudflat, homestead vegetation, and grassland (which includes grassy beach) because of the increasing LULC area of these. Grassland and homestead vegetation is increased in more hectare's area of the embankment and near embankment in accreted bear soil due to early stage of succession. And it also has negative impacts on cropland, green vegetation, and mangrove vegetation. Due to 
increased area migration of people are increased for that population density is the trend to high. People start to involve various professions due to the diversification of new working fields.

Moreover, Tourist attraction also increased due to the increasing area of sandy beach, which is the result of erosional activities. This study strongly recommended that if the sediments, which are deposited near the shore of the coast are properly used, and then it will be possible to gain new more land rather than the loss. So, authorities must be aware.

\section{References}

Abdul, H. M. \& Islam, R. M., 2005. Coastal Land Uses and Land Zones, Dhaka: Program Development Office ForIntegrated Coastal Zone Management Plan.

CDMP-II, 2014. Trend and Impact Analysis of Internal Displacement due to the Impacts of Disaster and Climate Change. Dhaka: Comprehensive Disaster Management Programme Phase II, Bangladesh: Ministry of Disaster Management and Relief. Retrieved from https://reliefweb.int/sites/reliefweb.int/files/resources/CDMP-Internal-Displacement-

Bangladesh-Analysis.pdf

Cooper, J. A. et al., 2004. Storm impacts on an embayed high energy coastline, Western Ireland. In: Mar Geol. s.1.:s.n., pp. 261-280.

Cui, B. \& Li, X., 2011. Coastline change of Yellow River estuary and its response to the sediment and runoff (1976-2005). In: Geomorphology. s.l.:s.n., pp. 32-40.

Dolan, R., Fenster, M. S. \& Holme, S. J., 1991. Temporal analysis of shoreline recession and accretion. Journal of costal Research, pp. 723-744.

FAO, 2005. Global Forest Resources Assessment 2005, s.1.: FAO Forestry Paper.

Fenster, M. S., Dolan , R. \& Morton , R. A., 2001. Coastal storms and shoreline change: signal or noise?. Journal of coast Research, Volume 9, pp. 714-720.

Fenster, M. S., Dolan, R. \& Elder, J. F., 1993. A new method for predicting shoreline positions from historical data. Journal of costal Resaerch, pp. 147-171.

Finch , J. W., 1997. Monitoring Small Dams in semi-arid Regions Using Remote Sensing and GIS. Journal of Hydrology, Volume 137, pp. 94-106. 
Forkuo, E. K. \& Frimpong, A., 2012. Analysis of Forest Cover Change Detection.. International Journal of Remote Sensing Applications, pp. 82-92.

Hasan, T. S., Syed, . A. M. \& Mamnun, N., 2017. s.l., Research Gate, pp. 115-124.

Hassan, M. I. \& Rahmat, . N. H., 2016. The effect of coastline changes to local community's social Economic. s.l., The International Archives of the Photogrammetry, Remote Sensing and Spatial Information Sciences, pp. 25-36.

Hossain, M. S., Rahman, M. F., Nabi, M. R. \& Kibria, M. M., 2013. Climate Change Resilience Assessment Using Livelihood Assets of Coastal Fishing Community in Nijhum Dwip, Bangladesh. Pertanika Journal of Sciecnce \& Technology, 21(2), pp. 397-422.

Jakobsen, F., Azam, M. H. \& Kabir, M. M.-u., 2000. Residula Flow in the Meghna Estuary on the Coastline of Bangladesh. Journal of Coastal and Shelf Science, Volume 55, pp. 587-597.

Li, R., Liu, J. \& Felus, Y., 2001. Spatial modeling and analysis for shoreline change detection and coastal erosion monitoring.. 24(01), pp. 1-12.

Maiti , S. \& Bhattacharya, A. K., 2009. Shoreline Change Analysis and Its application to prediction: A remote sensing and statistic based approach. Journal of marine geology, Volume 257, pp. 11-23.

McFeeters, S. K., 1996. The use of Normalized Difference Water Index (NDWI) in the Delineation of Open Water Features. International Journal of Remote Sensing, Volume 17(7), pp. $1425-1432$.

Milliman, J. D., 1991. Flux and Fate of Fluvial Sediment and Water in Coastal Seas. In: In, ed. R. F. C. Montoura, J. M. Martin, \& R. Wallast (Eds.). Chichester, UK: John Wiley \& Sons Ltd.

MoWR, 2005. Coastal Zone Policy, Dhaka, Bangladesh: Government of Bangladesh. Retrieved from http://nda.erd.gov.bd/files/1/Publications/Sectoral\%20Policies\%20and\%20Plans/CostalZone-Policy-2005.pdf

Mwanj, J. I., 1997. Socio-economic impacts of costal instability (Erosion) in Kenya.. UNESCOKenya National Seminar on Sustainable Coastal Development through Integrated Planning and 
Management Focused on Mitigating the Impacts of Coastline Instability, Whitesands Hotel, Mombasa, 23-25 June 1997 - Summary Report., pp. 26-40.

Orford, J. D., Forbes , D. L. \& Jennings, S. C., 2002. Organizational controls, typologies and time scales of paraglacial gravel-dominated coastal systems. In: Geomorphology. s.l.:s.n., pp. 5185.

Pajak, M. J. \& Leatherman, S., 2002. The high water line as shoreline indicator. Journal of coast research, Volume 18, pp. 329-337.

PDO-ICZMP, 2004. Contribution of Integrated Coastal Zone Management Plan Project towards Formulation of the Poverty Reduction Strategy Paper (PRSP) for BANGLADESH, Dhaka: Ministry of Water Resources, Bangladesh. [Online] Available at:

https://aquadocs.org/bitstream/handle/1834/7339/ktf0327.pdf?sequence=1\&isAllowed=y

Pidwirny, M., 2006. Plant Succession. 2nd ed. New York: McGraw-Hill. [Online] Available at: http://www.physicalgeography.net/fundamentals/9i.html

Rabbi, G. M., 2009. Doccumanting and registrating biodiversity of Nijhum Dwip, Noakhali, Dhaka: University of Dhaka.

Rahman, M. M., 2010. Offshore Nijhum island: Overcoming climate change impact. [Online] Available at: $\quad$ https://www.thedailystar.net/news-detail-133670

[Accessed 15 June 2018].

Rahman, M. M., 2010. Offshore Nijhum island: Overcoming climate change impact. [Online] Available at: $\quad$ https://www.thedailystar.net/news-detail-133670

[Accessed 20 August 2019].

Salek, A., Amin, J. \& Takashi, Y., 2001. Tide-Surge Interaction in the Meghna Estuary: Most Severe Conditions. Journal Physical Oceanography, Volume 31, pp. 3059-3072.

Sattar, S A; Mutsaers, H J W, 2004. Agriculture in Southeastern Coastal Chars of Bangladesh, s.1.: CHAR DEVELOPMENT \& SETTLEMENT PROJECT II. 
Shaha, P. K. et al., 2014. A Study on the management strategies of protected area in Bangladesh for biodiversity conservation on Nijhum Dwip, Noakhali, Bangladesh.. International Journal of Innovative Research and Development, Volume 3(7), pp. 140-148.

Thieler, E. R., Himmelstoss, E. A., Zichichi, J. L. \& Eragul, A., 2017. Digital Shoreline Analysis System (DSAS) Version 4.4 - An ArcGIS Extention for calculating Shoreline Change, s.l.: U.S Geological Survey Open-File Report 2008-1278.

Warren , R. S. \& Niering, W. A., 1993. Vegetation Change on a Northeast Tidal Marsh: Interaction of Sea-Level Rise and Marsh Accretion. Ecological Society of America, 74(1).

Wilde, K. d., 2011. Moving Coastlines: Emergence and use of Land in the GangesBrahmaputra-Meghna Estuary. In: Dhaka: University Press Ltd. 